\title{
O sistema brasileiro de instituições financeiras subnacionais para o desenvolvimento: um panorama
}

\author{
Victor Leonardo de Araujo \\ Professor adjunto da Faculdade de Economia da UFF \\ Murilo José de Souza Pires \\ Técnico de Planejamento e Pesquisa do Ipea na \\ Diretoria de Estudos e Políticas Regionais, \\ Urbanas e Ambientais (Dirur) \\ Márcio Francisco da Silva \\ Doutorando em Economia pela UnB \\ Diego Afonso de Castro
} Analista de Comércio Exterior do MDIC

\section{Palavras-chave}

bancos estaduais de desenvolvimento, agências de fomento, financiamento do desenvolvimento.

Classificação JEL O54, G21.

\section{Key words \\ state development banks, development agencies, development financing}

JEL Classification $054, G 21$.

\section{Resumo}

O objetivo deste trabalho é oferecer um panorama sobre a experiência brasileira recente com o sistema composto das instituições financeiras públicas que chamaremos de "subnacionais", voltadas para o financiamento do desenvolvimento: um banco regional de desenvolvimento, três bancos estaduais de desenvolvimento e 13 agências estaduais de fomento. Em geral, esse sistema é débil, possui fontes de funding pouco diversificadas e depende do BNDES e dos governos estaduais. As operaçôes de crédito oriundas das instituiçôes financeiras subnacionais para o desenvolvimento (IFDs-SN) são qualitativamente distintas das dos bancos públicos federais brasileiros. Salvo o setor comercial, em todos os demais as operaçôes de crédito cresceram a taxas inferiores à média do Sistema Financeiro Nacional (SFN) ou mesmo dos bancos públicos, à exceçáo do ano de 2009, revelando que as IFDs-SN contribuíram para a ação anticíclica implementada pelos bancos públicos brasileiros após a crise financeira internacional.

\section{Abstract}

This study aims to provide an overview of the recent Brazilian experience with public, subnational financial institutions for development (IFD-SN), composed by: a regional development bank, three state development banks and 13 state development agencies. In general, this system is weak, having few diversified funding sources, which rely on the National Economic and Social Development Bank and the state governments. Credit operations offered by IFD-SN are qualitatively distinct from the Brazilian federal banks: they grew at rates below the average for the National Financial System or even of the public banks. 


\section{1_Introdução}

Entre os vários temas inerentes ao problema do desenvolvimento, um que desperta interesse especial é a problemática do financiamento ao investimento, sobretudo em economias como a brasileira, que iniciou o seu processo de industrialização tardiamente. A necessidade imperiosa de realizar vultosos investimentos em diferentes setores da economia para garantir a diversificação produtiva e, com isso o seu desenvolvimento econômico, esbarra na necessidade de mobilização de recursos financeiros consideráveis que façam face às demandas de uma economia urbana e industrial que está em processo de transformação, mas que apresenta restrição interna, ou seja, escassez de financiamento de longo prazo, em particular, para aqueles setores econômicos que denotam baixa rentabilidade e longo período de maturação.

No caso brasileiro, as autoridades econômicas instituíram, em 1952, o Banco Nacional de Desenvolvimento Econômico (BNDE) ${ }^{1}$ como principal agente público responsável pelo financiamento de longo prazo. Com a expansão das atividades desse banco nos anos que se seguiram, a tendência de utilização de instituições públicas de fomento alcançou também as unidades federativas: as décadas de $1960 \mathrm{e}$ 1970 assistiram à criação de diversos bancos públicos estaduais de desenvolvimen- to, que atuavam de forma complementar ao BNDES, agindo sobretudo como agentes repassadores de recursos e constituindo-se como importantes agentes locais de fomento (Cavalcante, 2007). Esses bancos viriam a compor, ao lado do BNDES, aquilo que Pinto, De Paula e Salles (2007, p. 144) chamam de "Sistema Público Nacional de Fomento".

A crise econômica da década de 1980 e as reformas de caráter neoliberais que se iniciaram com maior profundidade na economia nacional, a partir da década de 1990 , provocaram o desmonte do sistema público de financiamento, culminando, assim, com a privatização, o fechamento e as transformaçóes de diversos bancos estaduais em agências de fomento. Atualmente, o formato institucional do sistema de fomento brasileiro diferencia-se daquele que vigorava no período desenvolvimentista (1930-1980) pela presença das agências de fomento, as quais, acrescidas de dois bancos estaduais de desenvolvimento e de um banco regional de desenvolvimento, integram, ao lado dos bancos públicos federais, o Sistema Público Nacional de Fomento.

O objetivo deste trabalho é oferecer um panorama geral sobre a experiência brasileira recente com o sistema composto de instituiçóes financeiras públicas, que chamaremos de "subnacionais", voltadas para o financiamento do desenvolvimen-
${ }^{1} \mathrm{O}$ "S" de "Social" somente será acrescentado em 1982. 
${ }^{2}$ Dados disponíveis em: $<$ https://www3.bcb.gov.br/ iftimagem>. Acesso em: agosto de 2010 .

${ }^{3}$ Tabela 7019 do BCB.

${ }^{4}$ A Tabela 7019 do BCB distingue as operações de crédito ao setor público voltadas para as administraçóes direta e indireta. No caso das IFDs-SN, estas últimas assumem valores meramente residuais, de modo que trabalharemos apenas com os totais. Pelo mesmo motivo, as operaçóes voltadas para habitação, intermediários financeiros e não residentes serão desconsideradas em nossa análise, embora façam parte das estatísticas divulgadas pelo BCB. to: um banco regional de desenvolvimento, três bancos estaduais de desenvolvimento e 13 agências estaduais de fomento. Pretende-se mostrar que, em geral, tal sistema é débil, possuindo fontes de funding pouco diversificadas, dependentes do BNDES e dos governos estaduais. Por outro lado, as operaçóes de crédito oriundas das IFDs-SN parecem ser qualitativamente distintas das dos bancos públicos federais brasileiros, por exemplo, ao privilegiar os setores de pessoas físicas - aqui entendidas, como se verá mais adiante, como microempreendedores.

Para cumprir os objetivos da pesquisa, foram utilizados preferencialmente dados referentes às informaçóes financeiras trimestrais (IFTs) disponibilizados pelo Banco Central do Brasil (BCB), ${ }^{2}$ especificamente as tabelas com os balanços patrimoniais e os saldos das operaçóes de crédito por setor. O período de estudo compreende o interregno de 2001, o primeiro ano para o qual existem as informaçóes financeiras trimestrais, a 2009. Foram utilizadas variáveis que captam estoque - incluindo o saldo das operaçóes de crédito -, e as informaçôes anuais referem-se sempre ao último trimestre de cada ano.

Os dados do balanço patrimonial foram reagrupados de modo a permitir identificar, na composição do passivo, os recursos próprios vis-à-vis os repasses de ins- tituiçóes oficiais, sobretudo os do BNDES. Evidentemente, o objetivo foi mapear a estrutura de funding das instituições financeiras subnacionais para financiamento do desenvolvimento (IFDs-SN), ressaltando o papel desse banco.

Também com dados do balanço patrimonial, foi possível analisar a composição do ativo das IFDs-SN, procedendo-se novamente um reagrupamento das contas, de modo a permitir enxergar as operações de crédito em face das operações com títulos e valores mobiliários (TVMs). A análise da composiçáo do ativo foi complementada por outra tabela do $\mathrm{BCB},{ }^{3}$ em que as operaçóes de crédito são desagregadas conforme os setores institucional e econômico. Novamente, os dados foram reagrupados conforme os objetivos propostos para esta pesquisa: o crédito segundo os setores institucional e econômico foram reagrupados em setor público (municipal/estadual) versus setor privado; e o crédito ao setor privado, por sua vez, foi desagregado conforme o setor de atividade, sendo considerados: rural, indústria, comércio, outros serviços e pessoas físicas. ${ }^{4}$

Este artigo é composto de oito seções, incluindo a presente introdução. $\mathrm{Na}$ seçáo 2, será apresentado o referencial teórico que justifica a existência de instituiçóes financeiras voltadas para fomentar o desenvolvimento econômico. O objetivo é 
apresentar algumas teorias de forma sucinta, sem exaurir o debate. $\mathrm{Na}$ seção 3, serão mostrados os antecedentes históricos das IFDs-SN. A seção 4 oferecerá um panorama geral dessas instituiçóes. A seção 5 discutirá a estrutura de funding das IFDs-SN, ao passo que a seção 6 analisará a composição das operações de crédito por setor. A seção 7 discutirá os prazos dessas operações, e a seçâo 8 fará as consideraçôes finais.

\section{2_Referencial teórico}

A literatura econômica registra diversos trabalhos nos quais os bancos de desenvolvimento constituem objeto de análise, quer se trate da sua definição, atuação histórica, quer se trate de funcionalidade.

Diamond (1957) define banco de desenvolvimento simplesmente como uma instituição destinada a conceder empréstimos de longo prazo (p. 2). Para Yeyati et al. (2004, p. 16), não há uma definição universalmente aceita para banco de desenvolvimento, mas esse tipo de instituição é geralmente descrito como provedor de capital de longo prazo para projetos imbuídos de externalidades, mas que, contudo, não encontram financiadores privados, como, por exemplo, financiamento agrícola e projetos de redução de desigualdades regionais. Boskey (1959) e Aghion (1999) enfatizam o papel de financiamento de longo prazo dessas instituiçóes. United Nations (2005) mostra que essa é uma característica comum nas várias definições para tal tipo de instituição, contudo procura refiná-la, distinguindo três outras funções comuns aos bancos de desenvolvimento: (i) o desenvolvimento econômico, que seria uma função histórica desse tipo de banco; (ii) objetivos sociais; e (iii) integração regional. Assim, United Nations (2005, p. 10-11) define os bancos de desenvolvimento da seguinte maneira: "Instituições financeiras destinadas a acelerar o desenvolvimento econômico, frequentemente considerando objetivos de desenvolvimento social e integração regional, principalmente provendo ou facilitando o financiamento de longo prazo de projetos que geram externalidades positivas".

A necessidade de bancos específicos para fomentar o desenvolvimento econômico é alvo de controvérsias na teoria econômica, contemplando pelo menos três abordagens. A primeira, a visão convencional, sintetizada no modelo Gurley e Shaw (1955), atribui ao mercado financeiro o papel de intermediar e transferir recursos das unidades superavitárias, compostas dos agentes poupadores, para as unidades deficitárias, representadas pelos agentes que consomem ou investem mais do que poupam. A taxa de juros, nesta abordagem, deve ser flexível o suficiente 


\footnotetext{
${ }^{5} \mathrm{O}$ modelo Gurley-Shaw e a hipótese de repressáo financeira geraram, como desdobramentos posteriores, trabalhos que tentaram provar a ineficiência de instituiçóes financeiras para o desenvolvimento. Ver, por exemplo, os trabalhos de Fry (1997), Vittas e Cho (1995) e Cho e Sheng (2002). Araujo (2007) resume esses estudos.

${ }^{6}$ Outra delas é a assimetria de informaçôes.
}

para equilibrar o mercado de fundos de empréstimo. O modelo Gurley-Shaw generaliza para os mercados financeiros os resultados segundo os quais o livre mercado promove a alocação mais eficiente dos recursos. Esse modelo, em conjunto com a hipótese de repressão financeira formulada por Shaw (1973) e McKinnon (1973), forma o corpo teórico básico da liberalização dos mercados financeiros. De acordo com tal hipótese, em economias em que a taxa de juros real é artificialmente baixa, os mercados financeiros não se desenvolvem, porque os agentes não têm estímulo a poupar, e assim a economia fica relegada a operar com baixo nível de investimento e de crescimento. De acordo com a hipótese de repressão financeira, taxas de juros inferiores às de equilíbrio (market-clearinginterest rates) levam a outras distorçóes, entre as quais a maior alocação de recursos em projetos capital-intensivos ou em projetos menos lucrativos. Nesta abordagem, bancos de desenvolvimento, bancos públicos e crédito direcionado são as principais causas da repressão financeira e, por isso, devem ser evitados. ${ }^{5}$

A segunda abordagem salienta as falhas de mercado, segundo a qual os resultados previstos pela abordagem convencional não são alcançados graças à existência de falhas que impedem o bom funcionamento dos mercados. No caso específico dos mercados financeiros, a incompletude dos mercados seria a principal delas. ${ }^{6}$ Segundo Stiglitz (1993), em economias menos desenvolvidas, os mercados financeiros são incompletos: os mercados de capitais são fracos, e os mercados acionários, muitas vezes, inexistem. Os bancos privados, por sua vez, tendem a privilegiar os empréstimos de curto prazo, desinteressando-se daqueles projetos que, embora tenham alto retorno social, têm baixo retorno privado e alto risco. Essa situação justificaria a intervenção governamental. De acordo com Stiglitz (1993), o uso dos bancos de desenvolvimento seria uma forma bem-sucedida de solucionar esses problemas. Ainda segundo esse autor, em um ambiente de informação imperfeita, o processo de alocação deixa de ser baseado nos preços, e a hipótese de repressão financeira não mais faria nenhum sentido.

A terceira abordagem, pós-keynesiana, parte do princípio da demanda efetiva - segundo o qual os níveis de emprego e de renda da economia dependem dos gastos autônomos em investimento. O consumo induzido amplia esse impulso autônomo por meio do multiplicador. Essa abordagem inverte a causalidade de poupança para investimento, presente na abordagem convencional, de investimento para poupança (Keynes, 1936). O investimento, segundo os pós-keynesianos, depende das 
decisões dos empresários, tendo por base o retorno esperado dos ativos de capital, e o seu financiamento dependeria - em um sistema de moeda fiduciária em que os bancos têm a prerrogativa de criar moeda escritural (a partir, portanto, de uma operação meramente contábil) - da função de preferência pela liquidez dos bancos, ou seja, da disposição dos bancos em mobilizar os recursos iniciais para o empresário financiar o investimento. Uma vez implementado, o investimento, pelo efeito multiplicador, geraria uma renda, parte da qual seria destinada à poupança, exatamente na mesma proporção do investimento inicial. Contudo, os empréstimos obtidos no sistema bancário, por meio de fundos rotativos (finance), constituem para os empresários um passivo de curto prazo, inadequado à estrutura de longo prazo dos seus investimentos. Assim, os empresários precisam alongar a estrutura de seus passivos - processo que Keynes (1937) chamou de funding. ${ }^{7}$

O formato por meio do qual o funding será provido dependerá das características da estrutura do sistema financeiro.
Zysman (1983) identificou uma tipologia que permite classificar a estrutura financeira existente. Basicamente, haveria sistemas com base no mercado de capitais (capital market-based-systems) e sistemas com base no crédito (credit-based systems). No primeiro caso, emissão de açóes e debêntures de longo prazo constitui a mais importante fonte de financiamento de formação de capital, ao passo que, no segundo caso, o mercado de capitais é fraco, e as firmas dependem do crédito para obter recursos (além dos lucros retidos) (Studart, 1999, p. 163). Segundo Studart, em países em que
os canais de consolidação financeira não se desenvolvem de forma significativa, a acumulação requereu uma relação mais próxima entre bancos privados e empre- sas (do tipo grandes bancos alemáes) elou uma maior intervençâo governamental (como, por exemplo, a criação de bancos de desenvolvimento e politicas de crédito seletivo nos paises de industrialização recente). (Studart, 1999, p. 163)

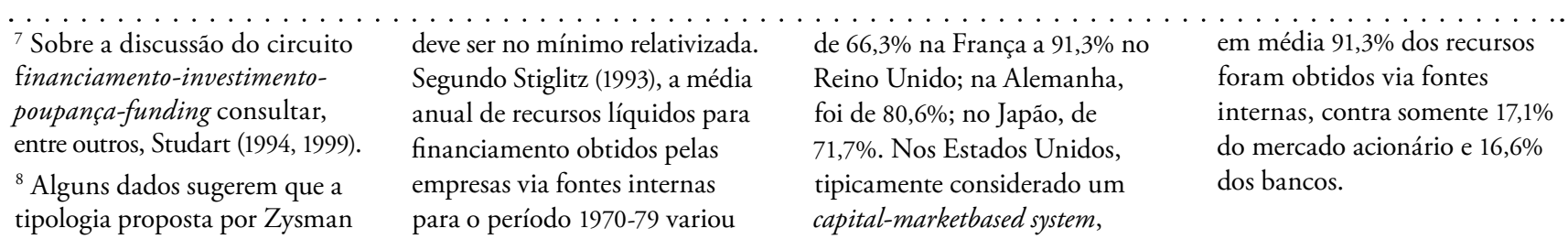


A formulação pós-keynesiana permite, assim, criticar as medidas de liberalização financeira sugeridas pela teoria neoclássica. Se é o investimento que determina a poupança, e não o contrário, não há porque perseguir políticas econômicas que busquem aumentar a poupança, mas sim políticas que permitam a formação de um arranjo institucional que garanta a oferta de funding. O aumento das taxas de juros, em vez de desejável por ampliar a poupança, é indesejável, porque resulta na contração dos investimentos.

Além disso, a formulação pós-keynesiana admite espaço para a atuação de bancos de desenvolvimento: a consolidação dos passivos de longo prazo constitui peça fundamental para a viabilização do investimento, não importando o formato institucional adotado. Neste sentido, essa abordagem não hierarquiza as soluções institucionais, diferentemente do que ocorre na abordagem neoclássica - que rejeita a priori o uso de bancos de desenvolvimento - ou a abordagem das falhas de mercados -, na qual o banco de desenvolvimento constitui solução tipo second best. Em outras palavras, na teoria pós-keynesiana não há nenhuma razão para supor, a priori, que mercados privados sejam capazes de prover o funding de forma superior à dos bancos de desenvolvimento.
Além de oferecer suporte teórico para a atuação de bancos de desenvolvimento, a teoria pós-keynesiana oferece espaço para a atuação de um sistema mais geral, composto dos bancos públicos. $\mathrm{O}$ ponto de partida é a compreensão do sistema bancário como um sistema de moeda fiduciária em que os bancos têm a prerrogativa de criar moeda escritural. A decisão dos bancos em conceder novos empréstimos depende da sua disposição em mobilizar os recursos iniciais para o empresário financiar a produção e o investimento. ${ }^{9}$ Dada a maior disposição em fazê-lo, os bancos devem administrar dinamicamente seus passivos e seus ativos. Nos momentos de maior incerteza - isto é, de deterioração do grau de confiança na manutenção das expectativas -, os bancos demandarão ativos mais líquidos, sob formas outras que não as operaçóes de crédito, especialmente as de prazos mais longos.

Em outras palavras, a disposição dos bancos em conceder crédito está atrelada à sua preferência pela liquidez. ${ }^{10} \mathrm{O}$ sistema financeiro produz e negocia direitos sobre renda futura, cujas estimativas envolvem risco, incerteza e graus variados de confiança nos cenários formulados (Hermann, 2009). Em cenários de maior incerteza, a defesa natural dos agentes econômicos em geral e dos bancos em par- 
ticular é reorientar seus portfólios a favor de ativos com maior grau de liquidez, abrindo mão da maior rentabilidade oferecida pelos ativos menos líquidos. Nesse sentido, é inerente à atuação dos bancos um comportamento pró-cíclico: em períodos de expansão econômica, essas instituições tendem a expandir suas operaçôes de crédito - para o que se faz necessária a emissão de obrigações (e, portanto, gestão de seus passivos) em volume a prazo adequado para viabilizá-las. Já em períodos de contração econômica ou de maior incerteza, os bancos tendem a privilegiar ativos mais líquidos e de prazo mais curto em lugar das operaçóes de crédito.

O comportamento da firma bancária descrito acima oferece espaço para a atuação de bancos públicos em pelo menos três funções. A primeira delas é a ação anticíclica, expandindo as operaçóes de crédito nos momentos de maior deterioração do estado de expectativas, quando os bancos privados tendem a reduzir as operaçóes de crédito em prol de ativos mais líquidos. A segunda é em relação ao financiamento de longo prazo. Essa função está associada aos maiores riscos e à menor liquidez nos quais são envolvidas as operaçóes de prazo mais longo. Inerentemente imbuídas de maior incerteza, essas operaçóes são menos visadas pelos bancos privados.
A terceira função é o financiamento do desenvolvimento regional e justifica-se a partir da aplicação dos conceitos keynesianos de incerteza e preferência pela liquidez às categorias de centro e periferia, em abordagem originalmente formulada por Dow (1982, 1987, 1990 apud Amado, 1997). ${ }^{11}$ Segundo essa abordagem, a periferia caracterizar-se-ia por possuir trajetória de crescimento mais instável, cuja dinâmica é exógena, com alta propensão a importar, estrutura produtiva concentrada nos setores primário e terciário, e tanto o grau de desenvolvimento dos mercados financeiros como o grau de liquidez dos ativos são baixos. Assim, o grau de incerteza nessas economias tende a ser mais elevado do que no centro; todavia, a preferência pela liquidez dos agentes econômicos também é mais elevada - e isso também é verdadeiro para as instituiçôes financeiras que nelas operam.

Esse quadro tende a gerar um círculo vicioso: os bancos ficam propensos a ofertar volumes relativamente menores de crédito para as economias periféricas, deslocando recursos para as regióes centrais e agravando as diferenças estruturais existentes (Nogueira; Crocco; Santos, 2010). "Não há mecanismos endógenos capazes de romper essa dinâmica concentradora. Portanto, a única forma de revertê-la é a introdução de elementos exóge-

\footnotetext{
${ }^{11}$ Recomenda-se também consultar Crocco et al. (2010).
} 
nos" (Amado, 2010, p. 221), e o elemento exógeno é justamente o Estado, via bancos públicos. Nesse sentido, instituições de atuação regional seriam preferíveis às de atuação nacional. Segundo Menezes et al. (2007, p. 303), “[...]bancos com sedes regionais tendem a gerar mais crédito porque possuem informações mais sólidas sobre a economia local e também se preocupam mais com o desempenho das empresas ali presentes, pois disso depende fortemente a sua sobrevivência”.

Com efeito, do ponto de vista do desenvolvimento regional, um banco com sede na periferia é preferível a um banco com sede no centro e filial na periferia: estes últimos, para compensar eventuais perdas na região periférica, tendem a voltar suas operaçóes para o centro, ao passo que os primeiros seriam mais comprometidos com a dinâmica econômica local. Segundo Amado (2010, p. 221),

"[...]a noção de proximidade relevante não é a de proximidade operacional ou física à rede de agências, mas sim à de proximidade funcional, onde o que importa é a distância em relação aos centros decisórios ou às matrizes, pois é nelas que o foco do processo decisório se encontra".

\section{3_Antecedentes históricos - a experiência brasileira com instituições financeiras para o desenvolvimento}

No Brasil, muito embora a experiência com bancos públicos com função de fomento date da fundaçáo do Banco do Brasil, em 1808 - e também de suas refundaçóes em 1853 e 1905 -, e posteriormente do Banco de Crédito da Borracha, de 1942, é somente em 1952, com a criação do BN$\mathrm{DE}$, que a economia brasileira pôde contar com um banco voltado especificamente para os projetos de desenvolvimento em curso após a Segunda Guerra Mundial.

A tendência de utilização de instituições públicas de fomento alcançou também as unidades federativas. Com o intuito de fomentar o desenvolvimento econômico regional, a década de 1960 assistiu à criação de diversos bancos públicos estaduais de desenvolvimento, em Estados como Minas Gerais (1962), Bahia (1966), Paraná (1968) e Espírito Santo (1969). O ano de 1962 também marcou a experiência pioneira de um banco interestadual de desenvolvimento: o Banco Regional de Desenvolvimento do Extremo Sul (BRDE), englobando os Estados do Rio Grande do Sul, de Santa Catarina e do Paraná. A experiência com IFDs estaduais prosseguiu na década seguinte: em 1970, surgiram ainda os Bancos de Desenvolvimento dos Esta- 
dos do Maranhão, do Ceará, de São Paulo, do Rio Grande do Norte; em 1974, foi a vez do Rio Grande do Sul, seguido do Rio de Janeiro em 1975, e, por fim, Goiás e Santa Catarina, ambos em 1977 (Cintra, 2009, p. 67-69). Ao longo dessas duas décadas, tais instituiçóes comporiam, ao lado do BNDES, aquilo que Pinto, De Paula e Salles (2007, p. 144) chamam de Sistema Público Nacional de Fomento, em que o BNDES seria o centro irradiador de políticas, e os bancos de desenvolvimento estaduais, os instrumentos de construção de oportunidades locais.

Essa tendência foi interrompida nas décadas de 1980 e 1990 . Com a eclosão da assim denominada "crise da dívida externa", os anseios desenvolvimentistas foram colocados em segundo plano no Brasil, em função da necessidade mais premente de promover o ajuste macroeconômico de curto prazo, reduzindo as taxas de crescimento do produto interno bruto (PIB) para compatibilizá-las com a restrição externa e com a crise fiscal. A década de 1980 foi especialmente marcante para as instituiçóes financeiras estaduais, que, atingidas pela crise, foram alvo de sucessivas intervençóes por parte do BCB. Em particular para os bancos estaduais de desenvolvimento, muitos sofreram dificuldades financeiras decorrentes de operaçóes arriscadas em razão do mau uso po- lítico por parte dos governos dos Estados controladores (Freitas, 2005) e quebraram, restando somente o Banco de Desenvolvimento de Minas Gerais (BDMG) e o Banco Regional de Desenvolvimento do Extremo Sul (BRDE).

Já as reformas estruturais de caráter liberalizante implementadas durante a década de 1990 distanciaram ainda mais os objetivos desenvolvimentistas da realidade brasileira. Particularmente, o lançamento do Programa de Incentivo à Redução da Participação do Setor Público Estadual na Atividade Financeira Bancária (Proes), em 1996, provocou o fechamento e a privatizaçáo de diversos bancos estaduais. A contrapartida oferecida pelo BCB aos governos estaduais foi a possibilidade de criação de agências de fomento, definidas como instituições não-financeiras, as quais, embora submetidas à regulamentação do $\mathrm{BCB}$, tinham o seu funcionamento restrito por uma série de regras específicas: não possuíam acesso à conta de reservas bancárias nem ao redesconto de liquidez ou aos depósitos interfinanceiros;as captaçóes eram limitadas a recursos de instituiçóes financeiras oficiais (como o BNDES) ou de fundos fiscais ou parafiscais; e obrigação de manter com recursos próprios um fundo de liquidez equivalente a $11 \%$ dos ativos ponderados pelo risco (Freitas, 2005, p. 21). 
Entretanto, não sendo instituiçōes financeiras, as agências ficavam totalmente inviabilizadas na prática. A bem da verdade, não havia propriamente uma preocupação de que as agências funcionassem efetivamente. Elas haviam sido basicamente moeda de troca do Governo Federal no processo de convencimento de governadores recalcitrantes em privatizar seus bancos estaduais. A mensagem politica era de que poderia subsistir ao menos um órgão explicitamente preocupado com o desenvolvimento econômico dos seus Estados. A filosofia de politica econômica era cética com relação aos benefícios que poderiam trazer as instituiçôes voltadas ao financiamento do desenvolvimento. (Freitas, 2005, p. 22)

O status de instituições financeiras às agências estaduais de fomento somente foi concedido em 2001, "o que lhes permitiu utilizar o instituto da alienação fiduciária em garantia, as células de crédito industrial e comercial, bem como a cobrança de encargos nos empréstimos nos mesmos moldes das instituições financeiras (antes limitado a 6\% [ao ano] a.a.)" (Pinto, De Paula, Salles, 2007, p. 150). Segundo Cavalcante (2007), foi somente a partir desse ano, com a publicação da Resolução n⿳o 2.828, do Conselho Monetário Nacional (CMN), que o con- ceito de agências de fomento "adquiriu um formato razoável e estável" (Cavalcante, 2007, p. 20). Para esse autor,

[...] do ponto de vista da regulamentação a que estão sujeitas, as agênncias de fomento nada mais são do que bancos de desenvolvimento com limitado escopo de atuação, na medida em que devem atender exigências de liquidez e alavancagem muito mais severas do que seus predecessores e estâo formalmente impedidas de captar depósitos.

(Cavalcante, 2007, p. 20)

Essas agências se diferenciam ainda de outras instituiçóes que compóem o Sistema Financeiro Nacional (SFN) por não terem acesso à poupança financeira $\mathrm{e}$ por não possuírem a prerrogativa de captar depósitos do público nem do mercado de capitais.

O escopo de atuação dessas instituições foi ampliado pela Resolução no3.757, do CMN, de 1o de julho de 2009, a qual as autorizou, entre outras coisas, a: i) captar depósitos interfinanceiros vinculados a operaçóes de microfinanças; ii) utilizar recursos de organismos e instituiçóes internacionais de desenvolvimento, desde que tenha obtido classificação de risco igual ou superior à União por agência internacional reconhecida; e 
iii) efetuar participação acionária direta ou indireta em empresas não financeiras, desde que em posição minoritária e em empresa não controlada pelo Estado.

Atualmente, existem em atuação 15 agências de fomento, dois bancos estaduais de desenvolvimento (Banco de Desenvolvimento do Espírito Santo - Bandes - e BDMG) e um banco regional de desenvolvimento (BRDE), que atende aos três Estados da regiáo Sul. Das agências atualmente em funcionamento, duas delas resultaram da conversão de antigos bancos de desenvolvimento: o antigo Banco de Desenvolvimento do Estado de Santa Catarina (BADESC) converteu-se na Agência de Fomento do Estado de Santa Catarina, preservando o antigo acrônimo; e o antigo Banco de Desenvolvimento do Estado da Bahia (Desenbanco) converteu-se na Agência de Fomento do Estado da Bahia (Desenbahia). A esse conjunto de instituições estamos denominando de IFD-SN. O uso dessa terminologia justifica-se para distingui-las, entre as IFDs integrantes do SFN, os bancos públicos federais e os bancos estaduais com carteira comercial que sobreviveram às desestatizaçóes da década de 1990 . Ou seja, as assim chamadas IFDs-SN têm em comum o fato de não serem controladas pelo governo federal nem possuírem a prerrogativa de captar depósitos à vista.
O Quadro 1, a seguir, apresenta o ano de fundação das IFDs-SN que compóem o objeto da presente pesquisa, além do BRDE.

\section{Quadro 1_IFDs-SNe BRDE - ano de fundação}

\begin{tabular}{|c|c|c|}
\hline Ano & Sigla & Agência \\
\hline 2009 & Afal & Agência de Fomento de Alagoas \\
\hline 2009 & $\begin{array}{l}\text { Nossa Caixa } \\
\text { Desenvolvimento }\end{array}$ & Agência de Fomento do Estado de São Paulo \\
\hline 2005 & Fomento & Agência de Fomento do Estado do Tocantins \\
\hline 2003 & MT Fomento & Agência de Fomento do Estado de Mato Grosso \\
\hline 2002 & InvestRio & Agência de Fomento do Estado do Rio de Janeiro \\
\hline 2001 & Desenbahia & Agência de Fomento do Estado da Bahia \\
\hline 1999 & AGN & Agência de Fomento do Rio Grande do Norte \\
\hline 1999 & Goiásfomento & Agência de Fomento de Goiás \\
\hline 1998 & AFAP & Agência de Fomento do Amapá \\
\hline 1998 & Afeam & Agência de Fomento do Estado do Amazonas \\
\hline 1997 & AFPR & Agência de Fomento do Paraná \\
\hline 1997 & AFERR & Agência de Fomento do Estado de Roraima \\
\hline 1997 & CaixaRS & Caixa Estadual S/A Agência de Fomento \\
\hline 1973 & BADESC & Agência de Fomento do Estado de Santa Catarina \\
\hline 1967 & Bandes & Banco de Desenvolvimento do Espírito Santo S/A \\
\hline 1962 & BDMG & Banco de Desenvolvimento de Minas Gerais \\
\hline 1961 & BRDE & $\begin{array}{l}\text { Banco Regional de Desenvolvimento } \\
\text { do Extremo Sul } \ldots \ldots \ldots \ldots \ldots \ldots\end{array}$ \\
\hline
\end{tabular}

Fonte: Dados coletados nos sítios na internet de cada IFD.

Elaboração dos autores. 
Gráfico 1_IFDs-SN - ativos totais em 2009(Em R\$ milhões) ${ }^{1}$

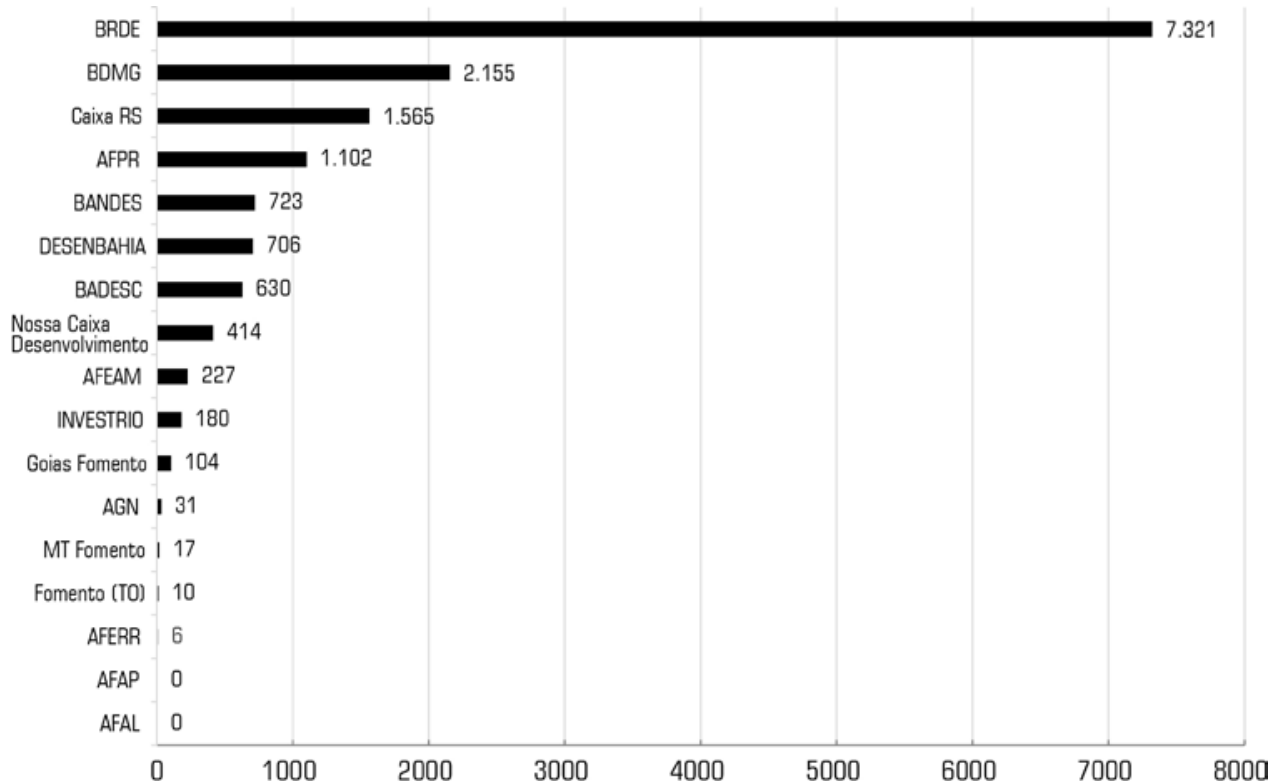

Fontes: BCB, Informaçóes Financeiras Trimestrais. Para AFERR, Afeam, AGN, Goiásfomento, FomenTO, Investe Rio, MT Fomentoe Nossa Caixa Desenvolvimento, dados fornecidos pela Associação Brasileira de Instituiçóes Financeiras para o Desenvolvimento (ABDE). Elaboração dos autores.

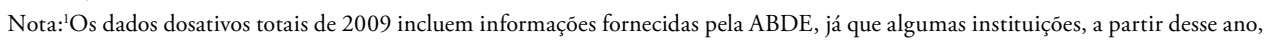
não possuem obrigatoriedade de divulgação das informaçôes contábeis devido ao seu porte.

\section{4_Panorama geral das IFDs}

As IFDs-SN que compóem o objeto da presente pesquisa totalizavam, em 2009 , ativos totais de ordem de R\$15,2 bilhóes, conforme o Gráfico 1, a seguir.

As informações contidas no Gráfico 1 permitem agrupar as IFDs-SN conforme o seu porte: BRDE, BDMG, CaixaRS e AFPR, com ativos totais acima de R $\$ 1$ bilhão, podem ser consideradas instituiçôes de grande porte, ao passo que AGN, MT
Fomento, FomenTO e AFERR, com ativos inferiores a R\$ 50 milhóes, podem ser consideradas de pequeno porte. Entre as instituiçóes que se encontram em patamar intermediário, observa-se nítida diferença: Bandes, Desenbahia e BADESC, com ativos totais entre R \$ 600 milhóes e $\mathrm{R} \$ 750 \mathrm{mi}$ lhôes, e o grupo formado por Nossa Caixa Desenvolvimento, Afeam, Investe Rio e Goiásfomento, cujos ativos totais são inferiores a $\mathrm{R} \$ 450$ milhóes. 


\section{Gráfico 2_IFD-SN - Ativos totais como proporção do PIB estadual (Em \%)}

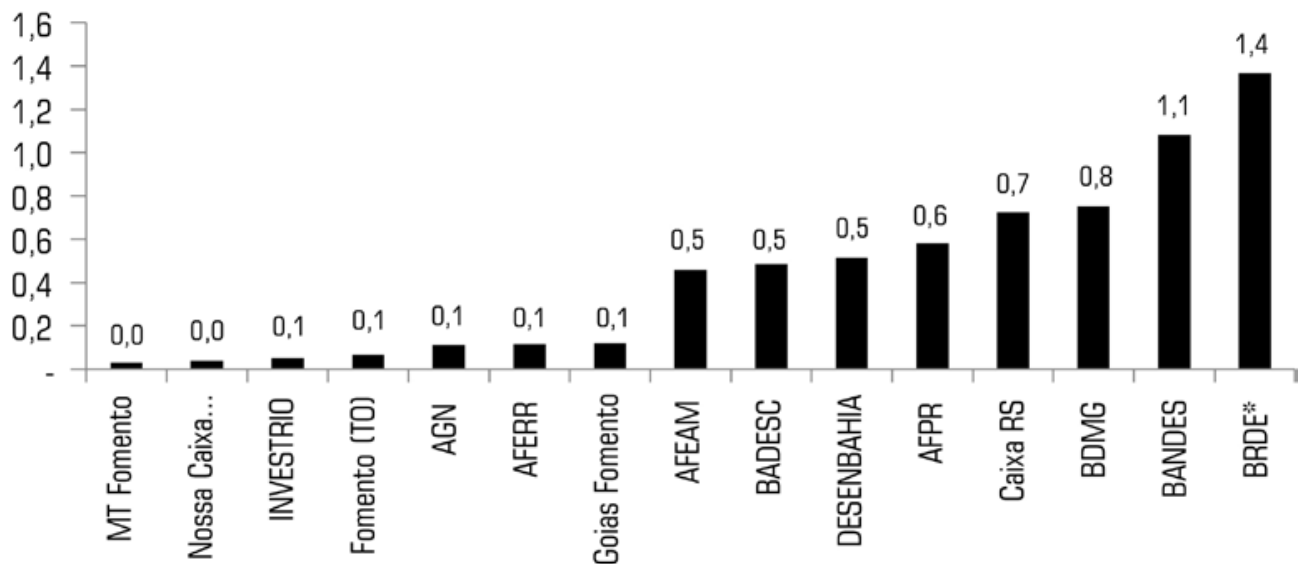

*O denominador considera os três estados que compōem a Região Sul

Fonte: BCB, Informaçôes Financeiras Trimestrais. Elaboração própria.

Entretanto, ativos totais em valores absolutos não parecem uma medida adequada para estabelecer o peso de cada instituição nas economias sob sua jurisdição. Assim, outra forma de dimensionar essas instituiçôes seria comparar os ativos totais com os PIBs de cada Estado. ${ }^{12} \mathrm{O}$ Gráfico 2, acima, apresenta essa relação. Sob essa perspectiva, o BANDES passa a adquirir importância quase similar ao BRDE e bastante superior ao BDMG, à CaixaRS e à AF$\mathrm{PR}$, ao passo que a AFEAM passa a assumir importância semelhante a seus congêneres de Santa Catarina e Bahia.

O tamanho dos ativos totais das IFDs-SN evidencia a existência de uma estrutura de fomento ao mesmo tempo im- portante e em alguns casos - como se verá adiante - débil para dar sustentação aos projetos de desenvolvimento implementados nos respectivos Estados. Tal estrutura nem sequer pode ser comparável àquela representada pelo conjunto dos bancos públicos federais. Para se ter uma ideia, os ativos totais do Banco da Amazônia S/A, por exemplo, são da ordem de $\mathrm{R} \$ 7,8$ bilhóes, superiores aos do BRDE, que, entre as IFDs-SN aqui estudadas, é a de maior porte. Quando comparados ao BNDES, cujos ativos totais eram de R \$ 379 bilhóes em 2009, os ativos totais das IFDs-SN representam somente $4 \%$.

Esse tipo de comparação é relevante não só para medir a ordem de grandeza

\footnotetext{
${ }^{12} \mathrm{O}$ mais convencional seria o uso da relação crédito/PIB. Contudo, como náo dispomos do total das operaçóes de crédito das instituições de pequeno porte (ver nota sob o Gráfico1), utilizamos a relação ativos/PIB. Apesar de pouco convencional, também constitui um indicador adequado usado, por exemplo, por Crocco et al. (2010).
} 
${ }^{13}$ Este assunto será discutido com maior nível de detalhamento mais adiante. das instituiçóes que constituem objeto desta pesquisa. Na verdade, na medida em que as agências de fomento e os bancos estaduais de desenvolvimento também atuam como agentes financeiros do BNDES, uma importante assimetria, já apontada por Cavalcante (2007), vem à tona: o BNDES é muito mais importante para as IFDs-SN do que estas últimas são para o primeiro.

De fato, a estrutura de funding das IFDs-SN é composta, basicamente, dos recursos repassados pelo BNDES e dos fundos estaduais por elas administrados. A capacidade de expansão das IFDs-SN por meio de recursos gerados a partir do orçamento dos respectivos governos estaduais é condicionada pelo dinamismo econômico dos Estados em que estâo circunscritas. A enorme heterogeneidade existente entre os Estados da Federação, com a existência de alguns muito pobres, com baixo dinamismo econômico, faz que os recursos repassados pelo BNDES sejam essenciais para muitas IFDs-SN. Entretanto, os limites de crédito que essas possuem no BNDES para cumprir o papel de agentes financeiros são condicionados a diversos fatores, entre eles um nível de alavancagem máximo definido com base no patrimônio de referência. ${ }^{13} \mathrm{Ou}$ seja, em última instância, IFDs-SN de menor porte tendem a receber volumes menores de recursos do BNDES.
Assim, o porte de cada IFD-SN é resultado não só do esforço implementado pelos respectivos governos estaduais, mas também de sua capacidade financeira em capitalizar essas instituiçóes, habilitando-as como agentes financeiros de maior vulto. Neste sentido, podem-se apontar como verdadeiras as seguintes proposiçóes: i) os Estados cujas economias são relativamente menos dinâmicas possuem as IFDs de menor porte; e ii) as IFDs-SN de maior porte estão localizadas em Estados de relativamente elevado dinamismo econômico. Evidentemente, tais proposiçôes não são capazes de abarcar os casos de IFDs-SN de pequeno porte localizadas em Estados de maior dinamismo econômico, como a Investe Rio e a Nossa Caixa Desenvolvimento, dos Estados do Rio de Janeiro e de São Paulo.

Tomadas em seu conjunto, as IFDs-SN que constituem o objeto deste trabalho foram responsáveis por operações de crédito que totalizaram $\mathrm{R} \$ 9,8$ bilhóes em 2009 (Gráfico 3). O SFN, tomado em seu conjunto, registrou, no mesmo ano, um saldo total de operaçóes de crédito direcionado no valor de R $\$ 460$ bilhôes. Ainda que não possam ser imediatamente comparados, esses dados evidenciam que o sistema composto das agências de fomento e dos bancos estaduais e regionais de desenvolvimento possui dimensóes modestas, 


\section{Gráfico 3_IFDs-SN - total das operaçóes de crédito (Em R\$ milhões de 2009)}

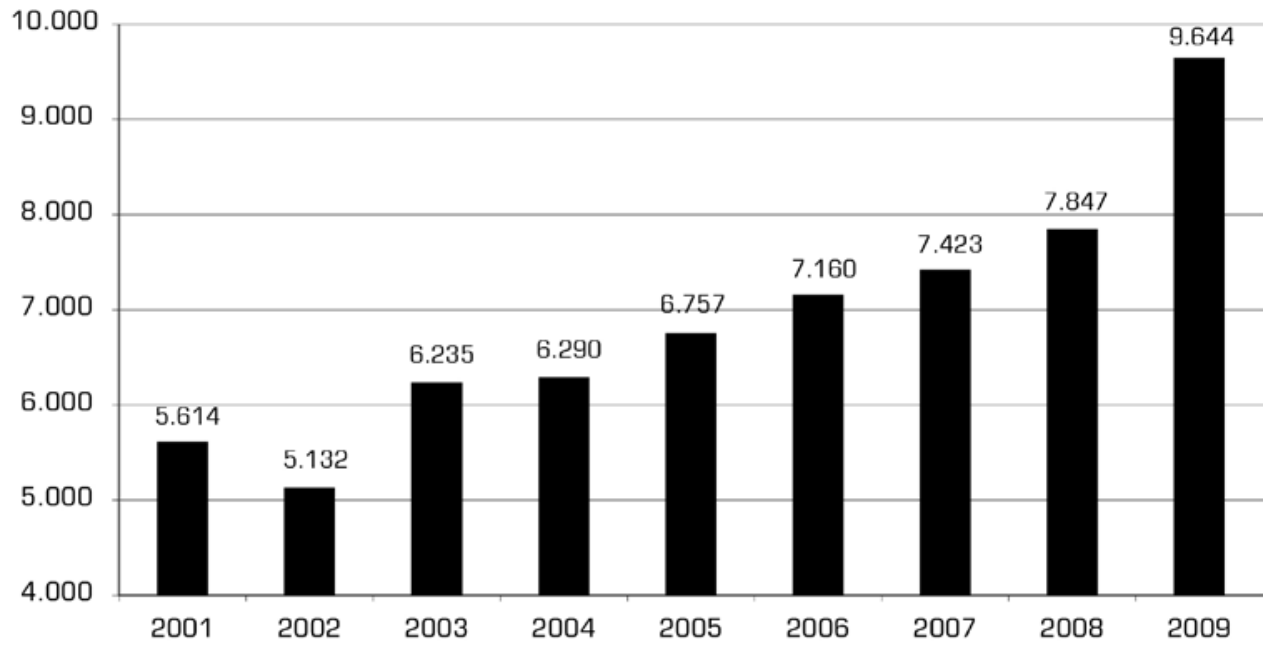

Fontes: BCB einformaçóes financeiras trimestrais. Em 2009, também foram utilizados dados fornecidos pela ABDE.

Elaboração dos autores.

Nota: 'Para 2009, as instituições com carteira de ativos inferior a R \$ 100 milhóes foram desobrigadas a enviar as informaçōes. Foram elas: AFERR, Afeam, AGN, Goiásfomento, FomenTO, Investe Rio, MT Fomento e Nossa Caixa Desenvolvimento. Portanto, para esse ano, o total das operaçóes de crédito agrega apenas BADESC, Bandes, BDMG, BRDE, CaixaRS, Desenbahia e AFPR. Ainda assim, esses valores são representativos, uma vez que as sete instituiçóes respondiam juntas por $96 \%$ dos ativos do conjunto de IFDs-SN em 2008.

não obstante a importância que representam para as economias dos territórios de seus respectivos Estados.

Apesar da dimensão modesta, as operaçóes de crédito via IFDs-SN seguem uma trajetória que, à semelhança do que ocorre com a média do SFN, pode ser dividida em duas partes: antes e depois de 2004. O ano é marcado pelo início do ciclo recente de crédito pelo qual passou a economia brasileira, quando a relação
crédito-PIB sai de um patamar de $24 \%$ para 45\% em 2009. ${ }^{14}$ Até em 2005, à exceção do BNDES, tanto as operaçóes de crédito via IFDs-SN como aquelas realizadas pelo SFN em seu conjunto registram trajetória instável. O ano 2005 marca uma inflexão na trajetória das IFDs-SN, mas ainda assim suas operaçóes de crédito crescem a taxas bastante modestas em comparação com o restante do sistema. Os dados denunciam que esse ciclo de
${ }^{14}$ Embora vários trabalhos datem do início do ciclo recente de crédito a partir de 2003 (Freitas; Prates, 2009; Cintra, 2009), preferimos considerá-los como de 2004. O leitor que acessar os dados do BCB notará que a taxa de crescimento real do crédito em 2003 é quase nula. A relação crédito-PIB, usualmente utilizada para caracterizar o ciclo de crédito, somente começa a se expandir de forma continuada a partir de janeiro de 2004. 
crédito foi induzido por um conjunto de instituições do qual as IFDs-SN não fizeram parte - estas últimas, inclusive, respondem com atraso à retomada do crédito na economia brasileira. A rigor, é fato que esse ciclo foi induzido, sobretudo pelos bancos privados, segmento para o qual o estoque de crédito cresceu a taxas superiores às do segmento composto dos bancos públicos. Mesmo se considerando o crédito direcionado, modalidade na qual atuam as IFDs-SN, é possível perceber que a taxa de crescimento do estoque de crédito dessas instituições foi sempre bastante inferior à média do SFN, situação que se modifica apenas em 2009. Trata-se de um ano no qual os bancos públicos expandiram suas operaçóes de crédito visando contra-arrestar a forte contração oriunda da banca privada. Neste sentido, é notável o caráter anticíclico da atuação das IFDs-SN.
As IFDs-SN também não conseguiram acompanhar o forte movimento de expansão registrado pelo BNDES, sobretudo em 2008, quando as operaçóes diretas desse banco foram expandidas em mais de $26 \%$, em termos reais, e as operaçóes de repasse, em quase $36 \%$. A relação entre as IFDs-SN e o BNDES será objeto de discussão mais detalhada adiante. Por ora, é suficiente ter em mente que, se o BNDES é a principal fonte de funding para muitas IFDs-SNe se as suas operaçóes de repasse, em geral, crescem a taxas muito superiores às das IFDs-SN, então é porque o BNDES tem privilegiado outras instituições como agentes financeiros.

Novamente, o estudo das razóes pelos quais isso ocorre deve passar pelas relações entre as IFDs-SN e o BNDES e também pela capacidade que os respectivos governos estaduais possuem de "turbinar" suas agências de fomento e seus bancos

Tabela 1_SFN, BNDES e IFDs-SN - total de operações de crédito, taxa de crescimento real (Em \%)

\begin{tabular}{|c|c|c|c|c|c|c|c|c|}
\hline & 2002 & 2003 & 2004 & 2005 & 2006 & 2007 & 2008 & 2009 \\
\hline IFDs-SN total & $(8,59)^{1}$ & 21,50 & $\mathbf{0 , 8 7}$ & 7,43 & 5,96 & 3,68 & 5,71 & 24,90 \\
\hline BNDES operaçóes diretas & 14,77 & 9,26 & $(10,90)$ & 10,30 & 4,20 & 0,69 & 26,14 & 49,29 \\
\hline BNDES operações de repasse & 52,02 & 17,87 & 20,56 & 15,51 & 20,79 & 31,61 & 35,60 & 20,96 \\
\hline Crédito direcionado SFN total & $(0,37)$ & 3,75 & $(1,09)$ & 11,11 & 10,97 & 9,01 & 17,86 & 31,38 \\
\hline Crédito SFN total & $(8,80)$ & 0,09 & 6,07 & 20,26 & 16,23 & 18,57 & 19,41 & 17,26 \\
\hline
\end{tabular}

Fontes: BCB e informaçôes financeiras trimestrais.

Elaboração dos autores.

Nota 1: Os números entre parênteses referem-se aos valores negativos. 
de desenvolvimento por meio dos fundos estaduais que compóem a sua estrutura de funding - e que também serão objeto de discussão mais adiante.

\section{5_Estrutura de funding das IFDs-SN}

Os componentes mais relevantes da estrutura de funding das agências de fomento são os recursos oficiais e os recursos próprios. De acordo com a Tabela 2, a seguir, em 2009, aproximadamente $54 \%$ do passivo desse conjunto de instituições referia-se a recursos oficiais, e o restante correspondia ao patrimônio líquido. Entre os recursos oficiais, o sistema BNDES representava 50\%, distribuídos entre BNDES (43\%) e Financiamento de Máquinas e Equipamentos (Finame) (7\%).

Evidentemente, o padrão de composição do passivo não é homogêneo entre as instituiçóes. De acordo com a Tabela 2, em 2008, BRDE, BDMG, Desenbahia e BADESC registravam as maiores concentraçóes de recursos do BNDES no seu passivo; do lado diametralmente oposto, estavam AGN e Afeam.

Aparentemente, esse padrão reflete muito mais as estratégias de composição do passivo de cada agência do que as estratégias do próprio BNDES. Isso porque o somatório de recursos oriundos do BNDES na composição do passivo de todas as IFDs-
-SN era de R \$ 5,4 bilhóes em 2008. Ademais, o desembolso do BNDES em operaçóes indiretas para as agências de fomento passa de R \$ 1,1 bilhão em 2006 (primeiro ano em que os dados foram disponibilizados) para R\$2,6 bilhões em 2009 (Tabela 4).

Os dados das Tabelas 1, 2 e 3, quando analisados em conjunto, permitem perceber que, se por um lado é verdade que as IFDs-SN, de modo geral, têm no BNDES uma de suas principais fontes de funding, por outro o BNDES não tem as IFDs-SN como principais instituições responsáveis por intermediar suas operaçóes indiretas. No período de 2006 a 2009, esse tipo de instituição respondeu por apenas cerca de $4 \%$, em média, das operações indiretas do BNDES. Entre as IFDs-SN, o BRDE é o que recebe o maior volume de desembolsos desse banco. Do universo de IFDs-SN, cinco instituiçóes nada receberam nos quatro anos: AFERR, AFAP, AGN, Fomento e MT Fomento.

Para compreender melhor as possíveis razóes que, por parte das IFDs-SN, podem induzir a um nível excessivamente baixo de utilização de recursos do BNDES, é preciso compreender a relação existente entre este último e seus agentes financeiros. Uma vez credenciada pelo BNDES $^{15}$ e atuando como repassadora de recursos dele oriundos, a instituição é enquadrada conforme o seu grau de relacionamento,
${ }^{15} \mathrm{O}$ credenciamento de uma instituição financeira como agente financeiro do BNDES somente ocorre mediante $o$ cumprimento de uma série de exigências estabelecidas por essa instituição: capacidade técnica para avaliação e acompanhamento das operações e dos projetos; capacidade e desempenho econômicofinanceirosuficientes para classificaçáo de risco mínimo B; e "documentos julgados necessários para o credenciamento, a critério do BNDES” (BNDES, 2010, p. 1). 
Tabela 2_Bancos federais e IFDs-SN - composição do passivo - 2008' (Em R\$ mil)

\begin{tabular}{|c|c|c|c|c|c|c|c|c|c|}
\hline & $\begin{array}{l}\text { 1. Passivo } \\
\text { circulante e } \\
\text { exigível em } \\
\text { longo prazo }\end{array}$ & $\begin{array}{l}1.1 \text { Recursos } \\
\text { captados junto } \\
\text { a mercados } \\
\text { privados }\end{array}$ & $\begin{array}{l}\text { 1.2 Recursos } \\
\text { oficiais }\end{array}$ & $\begin{array}{l}1.2 .1 \\
\text { Repasses } \\
\text { do país. } \\
\text { Instituições } \\
\text { oficiais }\end{array}$ & $\begin{array}{l}\text { a)Tesouro } \\
\text { Nacional }\end{array}$ & $\begin{array}{l}\text { b) Banco } \\
\text { do Brasil }\end{array}$ & c) BNDES & d) CEF & e) Finame \\
\hline Afeam & 92.337 & - & 82.885 & 3.516 & - & - & 2.473 & - & 1.043 \\
\hline AFPR & 82.355 & - & 1.980 & 1.980 & - & - & - & - & 1.980 \\
\hline AFERR & 535 & - & 362 & - & - & - & - & - & - \\
\hline FomenTO & 293 & - & - & - & - & - & - & - & - \\
\hline AGN & 7.647 & - & 4.168 & 4.168 & - & - & 732 & - & - \\
\hline BADESC & 181.156 & - & 125.081 & 125.081 & - & - & 120.271 & 0 & 4.149 \\
\hline Bandes & 515.384 & 97.583 & 387.876 & 268.956 & - & - & 205.617 & - & 6.759 \\
\hline BDMG & 1.058 .509 & - & 671.187 & 642.241 & 16.858 & - & 438.559 & 6.116 & 129.382 \\
\hline BRDE & 4.927 .411 & - & 4.682 .402 & 4.679 .734 & 162.377 & - & 3.928 .972 & - & 581.194 \\
\hline CaixaRS & 865.320 & - & 746.284 & 746.284 & - & - & 616.863 & 14.752 & 114.669 \\
\hline Desenbahia & 366.523 & - & 302.736 & 302.690 & 191 & - & 149.635 & - & 28.873 \\
\hline Goiásfomento & 6.853 & - & 325 & 325 & - & - & 325 & - & - \\
\hline Investe Rio & 66.021 & - & 43 & 43 & - & - & - & - & 43 \\
\hline MT Fomento & 858 & - & 74 & - & - & - & - & - & - \\
\hline $\begin{array}{l}\text { Total } \\
\text { IFDs-SN }\end{array}$ & 8.171 .202 & 97.583 & 7.005 .402 & 6.775 .017 & 179.425 & - & 5.463 .446 & 20.869 & 868.094 \\
\hline $\mathrm{BB}$ & 491.140 .080 & 388.827 .568 & 27.617 .213 & 22.409 .328 & 3.485 .066 & - & 11.167 .753 & - & 6.557 .872 \\
\hline $\mathrm{CEF}^{2}$ & 283.215 .660 & 218.272 .070 & 30.186 .265 & 29.120 .526 & 590.816 & - & 1.377 .309 & - & - \\
\hline BNDES & 246.825 .838 & 56.997 .152 & 87.679 .996 & 44.578 .609 & 37.561 .468 & - & - & 39.830 & 686.993 \\
\hline Basa & 5.354 .222 & 2.324 .703 & 1.839 .984 & 278.151 & 41.054 & - & 199.350 & 926 & 36.821 \\
\hline BNB. & 14.379 .717 & 5.665 .557 & 5.977 .882 & & 1.312 & - & 533.080 & 98 & 44.593 \\
\hline
\end{tabular}


Tabela 2_Bancos federais e IFDs-SN - composição do passivo - 2008' (Em R\$ mil)

\begin{tabular}{|c|c|c|c|c|c|c|}
\hline & $\begin{array}{l}\text { f) Outras } \\
\text { instituições }\end{array}$ & $\begin{array}{l}\text { 1.2.2 Fundos } \\
\text { financeiros e de } \\
\text { desenvolvi-mento }\end{array}$ & $\begin{array}{l}\text { 1.2.3. Obrigações } \\
\text { por emprés-timo }\end{array}$ & $\begin{array}{l}\text { 1.2.4 Obrigações } \\
\text { diversas }\end{array}$ & $\begin{array}{l}\text { 2. Patrimônio } \\
\text { líquido }\end{array}$ & Total do passivo \\
\hline Afeam & - & 79.369 & - & 9.452 & 96.993 & 189.330 \\
\hline AFPR & - & - & - & 80.375 & 937.421 & 1.019 .776 \\
\hline AFERR & - & 362 & - & 173 & 6.008 & 6.543 \\
\hline FomenTO & - & - & - & 293 & 9.352 & 9.645 \\
\hline AGN & 3.435 & - & - & 3.480 & 17.906 & 25.554 \\
\hline BADESC & 661 & - & - & 56.074 & 413.856 & 595.011 \\
\hline Bandes & 56.579 & 118.920 & - & 29.925 & 122.651 & 638.035 \\
\hline BDMG & 51.326 & 28.946 & - & 387.322 & 936.037 & 1.994 .547 \\
\hline BRDE & 7.191 & 2.668 & - & 245.008 & 1.023 .645 & 5.951 .056 \\
\hline CaixaRS & - & - & - & 119.036 & 392.435 & 1.257 .754 \\
\hline Desenbahia & 123.991 & 46 & - & 63.787 & 328.290 & 694.813 \\
\hline Goiásfomento & - & - & - & 6.529 & 88.608 & 95.461 \\
\hline Investe Rio & - & - & - & 65.978 & 36.376 & 102.396 \\
\hline MT Fomento & - & 74 & - & 785 & 14.284 & 15.143 \\
\hline $\begin{array}{l}\text { Total } \\
\text { IFDs-SN }\end{array}$ & 243.184 & 230.385 & - & 1.068 .217 & 4.423 .862 & 12.595 .064 \\
\hline $\mathrm{BB}$ & 1.198 .637 & 2.457 .799 & 2.750 .087 & 74.695 .299 & 29.937 .250 & 521.077 .330 \\
\hline $\mathrm{CEF}^{2}$ & 27.152 .401 & 1.065 .739 & - & 34.757 .325 & 12.704 .670 & 295.920 .330 \\
\hline BNDES & 6.290 .318 & 30.024 .857 & 13.076 .529 & 102.148 .690 & 25.266 .620 & 272.092 .458 \\
\hline Basa & - & 1.456 .180 & 105.653 & 1.189 .535 & 1.885 .558 & 7.239 .780 \\
\hline BNB & 654.004 & 4.667 .188 & 77.606 & 2.736 .279 & 1.797 .518 & 16.177 .235 \\
\hline
\end{tabular}

Fontes: Afeam, BCB einformaçốes financeiras trimestrais.

Elaboração dos autores.

Notas: 1 Nas Tabelas 2 e 3, utilizam-se dados referentes a 2008, porque os dados de 2009 não estão disponíveis para todas as instituiçóes.

${ }^{2}$ Caixa Econômica Federal.

${ }^{3}$ Banco do Nordeste do Brasil. 
Tabela 3_Bancos federais e IFDs-SN -composição do passivo - 2008 (Em \%)

\begin{tabular}{|c|c|c|c|c|c|c|c|c|c|}
\hline & $\begin{array}{l}\text { 1. Passivo } \\
\text { circulante } \\
\text { e exigível } \\
\text { em longo } \\
\text { prazo }\end{array}$ & $\begin{array}{l}1.1 \text { Recur- } \\
\text { sos capta- } \\
\text { dos junto a } \\
\text { mercados } \\
\text { privados }\end{array}$ & $\begin{array}{l}\text { 1.2 Recursos } \\
\text { oficiais }\end{array}$ & $\begin{array}{l}\text { 1.2.1 } \\
\text { Repasses } \\
\text { do país. } \\
\text { Instituições } \\
\text { oficiais }\end{array}$ & $\begin{array}{l}\text { a) Tesouro } \\
\text { Nacional }\end{array}$ & $\begin{array}{l}\text { b) Banco do } \\
\text { Brasil }\end{array}$ & c) BNDES & d) CEF & e) Finame \\
\hline Afeam & 48,77 & - & 43,78 & 1,86 & - & - & 1,31 & - & 0,55 \\
\hline AFPR & 8,08 & - & 0,19 & 0,19 & - & - & - & - & 0,19 \\
\hline AFERR & 8,17 & - & 5,53 & - & - & - & - & - & - \\
\hline FomenTO & 3,04 & - & - & - & - & - & - & - & - \\
\hline AGN & 29,93 & - & 16,31 & 16,31 & - & - & 2,87 & - & - \\
\hline BADESC & 30,45 & - & 21,02 & 21,02 & - & - & 20,21 & 0,00 & 0,70 \\
\hline Bandes & 80,78 & 15,29 & 60,79 & 42,15 & - & - & 32,23 & - & 1,06 \\
\hline BDMG & 53,07 & - & 33,65 & 32,20 & 0,85 & - & 21,99 & 0,31 & 6,49 \\
\hline BRDE & 82,80 & - & 78,68 & 78,64 & 2,73 & - & 66,02 & - & 9,77 \\
\hline CaixaRS & 68,80 & - & 59,33 & 59,33 & - & - & 49,04 & 1,17 & 9,12 \\
\hline Desenbahia & 52,75 & - & 43,57 & 43,56 & 0,03 & - & 21,54 & - & 4,16 \\
\hline Goiásfomento & 7,18 & - & 0,34 & 0,34 & - & - & 0,34 & - & - \\
\hline Investe Rio & 64,48 & - & 0,04 & 0,04 & - & - & - & - & 0,04 \\
\hline MT Fomento & 5,67 & - & 0,49 & - & - & - & - & - & - \\
\hline Total IFDs-SN & 64,88 & $\mathbf{0 , 7 7}$ & 55,62 & 53,79 & 1,42 & - & 43,38 & 0,17 & 6,89 \\
\hline $\mathrm{BB}$ & 94,25 & 74,62 & 5,30 & 4,30 & 0,67 & - & 2,14 & - & 1,26 \\
\hline CEF & 95,71 & 73,76 & 10,20 & 9,84 & 0,20 & - & 0,47 & - & - \\
\hline BNDES & 90,71 & 20,95 & 32,22 & 16,38 & 13,80 & - & - & 0,01 & 0,25 \\
\hline Basa & 73,96 & 32,11 & 25,41 & 3,84 & 0,57 & - & 2,75 & 0,01 & 0,51 \\
\hline BNB. & $88,89$. & $35,02$. & $36,95$. & - & $0,01$. & - & $3,30$. & 0,00 . & 0,28 . \\
\hline
\end{tabular}


Tabela 3_Bancos federais e IFDs-SN -composição do passivo - 2008 (Em \%)

\begin{tabular}{|c|c|c|c|c|c|c|}
\hline & $\begin{array}{l}\text { f) Outras } \\
\text { instituições }\end{array}$ & $\begin{array}{l}\text { 1.2.2 Fundos } \\
\text { financeiros e de } \\
\text { desenvolvimento }\end{array}$ & $\begin{array}{l}\text { 1.2.3 brigações } \\
\text { por empréstimo }\end{array}$ & $\begin{array}{l}\text { 1.2.4 Obrigações } \\
\text { diversas }\end{array}$ & $\begin{array}{l}\text { 2. Patrimônio } \\
\text { líquido }\end{array}$ & $\begin{array}{l}\text { Total do } \\
\text { passivo }\end{array}$ \\
\hline Afeam & - & 41,92 & - & 4,99 & 51,23 & 100,00 \\
\hline AFPR & - & - & - & 7,88 & 91,92 & 100,00 \\
\hline AFERR & - & 5,53 & - & 2,65 & 91,83 & 100,00 \\
\hline FomenTO & - & - & - & 3,04 & 96,96 & 100,00 \\
\hline AGN & 13,44 & - & - & 13,62 & 70,07 & 100,00 \\
\hline BADESC & 0,11 & - & - & 9,42 & 69,55 & 100,00 \\
\hline Bandes & 8,87 & 18,64 & - & 4,69 & 19,22 & 100,00 \\
\hline BDMG & 2,57 & 1,45 & - & 19,42 & 46,93 & 100,00 \\
\hline BRDE & 0,12 & 0,04 & - & 4,12 & 17,20 & 100,00 \\
\hline CaixaRS & - & - & - & 9,46 & 31,20 & 100,00 \\
\hline Desenbahia & 17,85 & 0,01 & - & 9,18 & 47,25 & 100,00 \\
\hline Goiásfomento & - & - & - & 6,84 & 92,82 & 100,00 \\
\hline Investe Rio & - & - & - & 64,43 & 35,52 & 100,00 \\
\hline MT Fomento & - & 0,49 & - & 5,18 & 94,33 & 100,00 \\
\hline Total IFDs-SN & 1,93 & 1,83 & - & 8,48 & 35,12 & 100,00 \\
\hline $\mathrm{BB}$ & 0,23 & 0,47 & 0,53 & 14,33 & 5,75 & 100,00 \\
\hline CEF & 9,18 & 0,36 & - & 11,75 & 4,29 & 100,00 \\
\hline BNDES & 2,31 & 11,03 & 4,81 & 37,54 & 9,29 & 100,00 \\
\hline Basa & - & 20,11 & 1,46 & 16,43 & 26,04 & 100,00 \\
\hline BNB. & . . 4,04. & $28,85$. & 0,48 . & $16,91$. & 11,11 & 100,00 \\
\hline
\end{tabular}

Fontes: $\mathrm{BCB}$ einformaçōes financeiras trimestrais.

Elaboração dos autores. 
Tabela 4 Desembolsos do BNDES para IFDs-SN e bancos públicos federais em operações indiretas

\begin{tabular}{|c|c|c|c|c|c|c|c|c|}
\hline & $\begin{array}{l}2006 \\
\text { (R\$ milhões) }\end{array}$ & & $\begin{array}{l}2007 \\
\text { (R\$ milhões) }\end{array}$ & $(\%)$ & $\begin{array}{l}2008 \\
\text { (R\$ milhões) }\end{array}$ & $(\%)$ & $\begin{array}{l}2009 \\
\text { (R\$ milhões) }\end{array}$ & $(\%)$ \\
\hline Afeam & 0,31 & 0,00 & 2,13 & 0,01 & 0,39 & 0,00 & 9,76 & 0,02 \\
\hline AFERR & 0,00 & 0,00 & 0,00 & 0,00 & 0,00 & 0,00 & 0,00 & 0,00 \\
\hline AFAP & 0,00 & 0,00 & 0,00 & 0,00 & 0,00 & 0,00 & 0,00 & 0,00 \\
\hline AFPR & 0,65 & 0,00 & 0,00 & 0,00 & 0,00 & 0,00 & 0,00 & 0,00 \\
\hline AGN & 0,00 & 0,00 & 0,00 & 0,00 & 0,00 & 0,00 & 0,00 & 0,00 \\
\hline BADESC & 0,00 & 0,00 & 0,00 & 0,00 & 13,07 & 0,03 & 32,07 & 0,06 \\
\hline Bandes & 72,54 & 0,25 & 65,05 & 0,17 & 68,67 & 0,14 & 84,39 & 0,15 \\
\hline BDMG & 117,99 & 0,40 & 175,69 & 0,46 & 169,40 & 0,35 & 249,52 & 0,43 \\
\hline BRDE & 845,81 & 2,90 & $1.033,34$ & 2,72 & $1.326,65$ & 2,74 & $1.829,78$ & 3,15 \\
\hline CaixaRS & 144,34 & 0,49 & 208,07 & 0,55 & 150,38 & 0,31 & 433,70 & 0,75 \\
\hline Desenbahia & 9,48 & 0,03 & 15,15 & 0,04 & 18,92 & 0,04 & 18,56 & 0,03 \\
\hline FomenTO & 0,00 & 0,00 & 0,00 & 0,00 & 0,00 & 0,00 & 0,00 & 0,00 \\
\hline Goiásfomento & 0,32 & 0,00 & 0,12 & 0,00 & 0,08 & 0,00 & 0,00 & 0,00 \\
\hline InvesteRio & 0,21 & 0,00 & 0,00 & 0,00 & 0,00 & 0,00 & 0,62 & 0,00 \\
\hline MT Fomento & 0,00 & 0,00 & 0,00 & 0,00 & 0,00 & 0,00 & 0,00 & 0,00 \\
\hline Basa & 44,32 & 0,15 & 31,86 & 0,08 & 28,61 & 0,06 & 115,79 & 0,20 \\
\hline $\mathrm{BB}$ & $5.132,74$ & 17,58 & $6.338,41$ & 16,69 & $8.979,79$ & 18,53 & $12.232,55$ & 21,03 \\
\hline $\mathrm{BNB}$ & 0,83 & 0,00 & 0,13 & 0,00 & 8,56 & 0,02 & 282,21 & 0,49 \\
\hline CEF & 235,86 & 0,81 & 333,42 & 0,88 & 913,03 & 1,88 & $1.819,94$ & 3,13 \\
\hline TotalIFDs-SN . . . . . . . & $1.191,67$ & . 4,08 & $1.499,55$ & . .3,95 & $1.747,55$ & 3,61 & $2.658,39$ & . 4,57. \\
\hline Total de operaçóes indiretas & $29.195,52$ & 100,00 & $37.980,93$ & 100,00 & $48.463,47$ & 100,00 & $58.155,86$ & 100,00 \\
\hline
\end{tabular}

Fonte: BNDES.

Elaboração dos autores.

que pode variar de 1 a 3: quando classificado no grau 1 , o agente financeiro não apresenta restriçóes; no grau 2, apresenta restriçóes, mas cumpre "razoavelmente" suas obrigações no BNDES; e no grau 3, o agente financeiro apresenta restriçóes gra- ves. Essa classificação envolve critérios que vão desde o nível de utilização dos limites de crédito disponibilizados até o inadimplemento financeiro e não financeiro. $\mathrm{Os}$ critérios para definição dos limites de crédito disponibilizados envolvem limites de 
alavancagem aplicados sobre o patrimônio de referência: ${ }^{16}$ quanto maior for esse valor, maior será o limite de crédito.

Dessa forma, o esperado é que instituições de menor porte tenham limite inferior, dado que seus patrimônios de referência são relativamente inferiores. $\mathrm{O}$ critério, se por um lado penaliza as agências menores e as condena a um círculo vicioso, por outro se justifica com base em critérios de gestão de risco do próprio BNDES. Uma possível solução consistiria na realização de operaçóes, por parte dos tesouros estaduais, de capitalização de suas agências de fomento, de modo a expandir o patrimônio líquido - e também o patrimônio de referência e assim legitimá-las como agentes financeiros mais expressivos do BNDES.

Evidentemente, o tamanho do patrimônio de referência não é o único critério para determinar o porte da IFD-SN conquanto agente financeiro do BNDES. Critérios adicionais são levados em consideração. Um deles é o grau de utilização do limite de crédito por parte do agente financeiro: a existência de ociosidade ao término do exercício leva o BNDES a reduzir o limite para o exercício seguinte. Neste caso, diversos fatores podem contribuir para determinar a não utilização de recursos disponibilizados pelo BNDES, desde a falta de capilaridade da agência (que pode determinar uma demanda existente, porém não atendida) até a insuficiência de demanda por recursos do BNDES dada a existência de outras fontes mais competitivas. ${ }^{17}$

Outro elemento importante da estrutura de funding das agências de fomento são os recursos provenientes dos respectivos tesouros estaduais, geralmente decorrentes de fundos específicos criados pelos governos estaduais e cuja administração ou gestão é atribuída às IFDs-SN. Em muitos casos, o arranjo financeiro é formatado de tal forma que o risco da operação não pertence à instituição financeira, de modo que esta atua apenas na análise econômico-financeira do projeto e autoriza a liberação do recurso - ou seja, as operaçóes não são registradas no balanço patrimonial. Embora esses recursos não sejam o principal componente da estrutura de funding (como vimos anteriormente, o BNDES é quem cumpre tal papel, salvo algumas exceçóes), a sua análise é importante porque denota o esforço e a capacidade de cada governo estadual em garantir maior autonomia financeira às suas agências. Neste sentido, destacam-se a Afeam, o Bandes e o BDMG.

Outra importante fonte potencial de funding para as agências de fomento é constituída pelos fundos constitucionais. Criados pela Constituição Federal de 1988
${ }^{16}$ Calculado com base na ponderação dos riscos aos quais as instituições estão expostas.

${ }^{17}$ Como os fundos constitucionais, cujo papel será visto mais adiante. 
Tabela 5_FNE - bancos que receberam repasses, 2008

\begin{tabular}{l|l|l|r|r} 
& $\begin{array}{l}\text { Operações } \\
\text { contratadas }\end{array}$ & $\mathbf{( \% )}$ & Valor (R\$ mil) & $\mathbf{( \% )}$ \\
\hline AGN & 7 & 4 & 1.344 & 2,8 \\
\hline Banese & 148 & 84,1 & 20.213 & 41,7 \\
\hline Desenbahia & 21 & 11,9 & 26.868 & 55,5 \\
\hline Total $\ldots$ & $\mathbf{1 7 6}$ & $\mathbf{1 0 0}$ & $\mathbf{4 8 . 4 2 5}$ & $\ldots \ldots$ \\
\hline
\end{tabular}

Fonte: Brasil (2009a, p. 13).

${ }^{18}$ A partir de dezembro de 2007. Ver Araujo (2007).
(CF/88), os fundos constitucionais são estabelecidos pela destinação de 3\% da arrecadação do Imposto de Renda(IR) e do Imposto sobre Produtos Industrializados (IPI) para programas voltados ao desenvolvimento das regióes Norte, Nordeste e Centro-Oeste. A Lei no 7.827 , de 27 de setembro de 1989, criou, assim, o Fundo Constitucional do Norte (FNO), o Fundo Constitucional do Nordeste (FNE) e o Fundo Constitucional do Centro-Oeste (FCO), e seus agentes financeiros são, respectivamente, o Basa, o BNB e o BB.

A partir de 2003, o Ministério da Integração Nacional autorizou que outras instituições autorizadas a funcionar pelo BCB também pudessem operacionalizar com os recursos dos fundos. $\mathrm{O}$ intuito era descentralizar e tornar ágil a aplicação des- ses recursos. A Desenbahia foi a primeira agência de fomento autorizada a operar o FNE, a partir de janeiro de 2005. A lista inclui também a Goiásfomento ${ }^{18} \mathrm{e}$ a AGN. Entretanto, os fundos constitucionais ainda não compóem fonte expressiva de recursos para as IFDs-SN: de acordo com a Tabela 5, ao lado, das três instituições que receberam repasses do FNE em 2008, uma era o Banco do Estado do Sergipe (Banese), instituição que não pode ser considerada estritamente uma IFD.

A relação entre o FNO, o FCO e as IFDs-SN localizadas nos Estados das regióes Norte e Centro-Oeste é ainda menos intensa. O total repassado pelo FCO para instituiçóes do Centro-Oeste foi de R \$ 18,4 milhóes, e, das quatro receptoras (Banco Cooperativo do Brasil - BANCOOB, Banco Cooperativo Sincredi, Banco de Brasília e Goiásfomento) somente uma era IFD-SN (FCO apud Rosa, 2010). Já o caso do FNO é ainda pior: segundo o Basa (Brasil, 2009c, p. 13),

\section{[...] duas agências de fomento na Região} se candidataram para receber repasses do FNO pelo Banco da Amazônia, no exercicio de 2009[...]. O Banco disponibilizou, em 2009, $R \$ 15$ milhöes para repasses, contudo, essas agências não apresentaram capacidade técnica comprovada nem estrutura operacional e administrativa aptas a realizar, com 
segurança e no estrito cumprimento das diretrizes e normas estabelecidas, os programas de crédito do FNO [...].

Os fundos constitucionais poderiam constituir importante fonte de recursos para as IFDs-SN que operam nas regióes atendidas, porque as taxas de juros das operações são, via de regra, inferiores às taxas cobradas nas operaçóes de repasse do BNDES. No caso dos fundos constitucionais, as taxas de juros para operaçóes que envolvem a agricultura familiar podem variar de $0,5 \%$ a.a. a $5 \%$ a.a., e de $5 \%$ a $10 \%$ para os demais mutuários, sempre variando conforme a modalidade da linha de crédito (Brasil, 2009b). As operaçôes ain$\mathrm{da}$ incluem um bônus de adimplência concedido sobre os encargos financeiros, que tornam a operação ainda mais barata sempre que a parcela da dívida for paga até a data do respectivo vencimento. Já nas operações de repasse com recursos do BNDES, as taxas de juros partem da Taxa de Juros de Longo Prazo (TJLP), adicionadas da remuneração básica do BNDES e da remuneração da instituição financeira credenciada. Embora esta última seja limitada pelo BNDES, em geral o custo das operações acaba sendo significativamente superior ao custo envolvido nas operações feitas via fundos constitucionais.

\section{6_Composição setorial das operações de crédito}

A maior parte das operaçóes de crédito realizada pelas IFDs-SN tem sido destinada ao setor industrial. Entretanto, a participação relativa desse setor tem declinado desde o ano inicial da série, 2001, quando correspondia a $46 \%$, estabilizando-se em torno de 30\% a partir de 2006 (Gráfico 4). As modalidades relativas a outros serviços e ao setor rural, que em 2001 ocupavam a segunda e terceira posição respectivamente, perderam posição para o crédito a pessoas físicas, que registrou forte crescimento ao longo do período considerado. O primeiro mantém estável sua participação até 2007 , declinando somente a partir de 2007, ao passo que o segundo chegou a registrar expansão mais notável em 2004, até declinar em 2007. Por fim, o crédito ao setor de comércio vem elevando gradualmente sua participação na carteira de crédito das IFDs-SN, e em 2007 e 2008 essa expansão é mais expressiva.

Cabe neste trabalho um esclarecimento: o segmento de pessoas físicas, para o caso das IFDs-SN, adquire conotação diferente daquela utilizada pelos bancos comerciais. Para o caso das IFDs-SN, o financiamento registrado na modalidade de pessoas físicas refere-se a empréstimos realizados por linhas de crédito direcionadas para microempresários e profissionais 


\section{Gráfico 4_IFD-SN - distribuição do crédito por setor - 2001-20091}

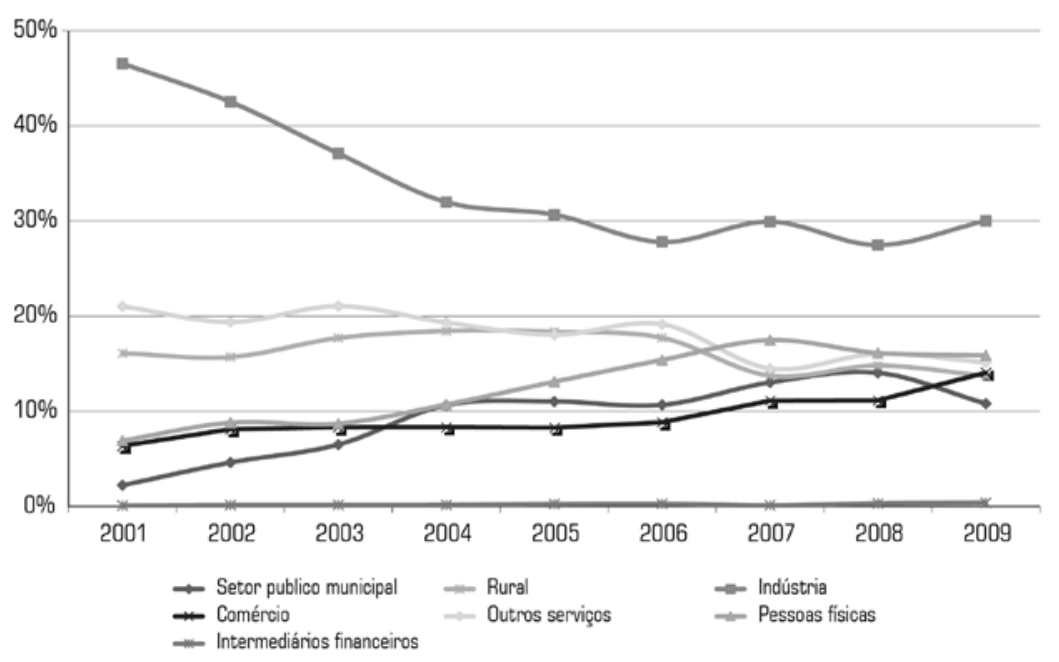

Fontes: $\mathrm{BCB}$ einformaçōes financeiras trimestrais.

Elaboração dos autores.

Nota: ${ }^{1} \mathrm{O}$ ano de 2009 compreende apenas BADESC, Bandes, BDMG, BRDE, CaixaRS, Desenbahia e AFPR. Ver nota 1 do Gráfico 2.

\section{1_Crédito industrial}

$\mathrm{O}$ crédito ao setor industrial a partir das IFDs-SN apresenta trajetória bastante instável. O pior momento consiste na passagem de 2003 para 2004, quando, em termos reais, a queda foi de $13 \%$, passando de $\mathrm{R} \$ 2,3$ bilhões para $\mathrm{R} \$ 2$ bilhóes (Tabela 6). O estoque manteve-se nesse patamar até 2006, voltando a expandir-se em 2007, e só superando os valores de 2001 em 2009, quando atingiu pouco menos de $\mathrm{R} \$ 2,9 \mathrm{bi}$ lhôes. Os dados permitem perceber que, ao menos na modalidade de crédito ao setor industrial, as IFDs-SN não replicaram o comportamento médio do SFN nem o dos bancos públicos. Para a média do período 2001-2009, o crédito total ao setor industrial cresceu, em termos reais, à taxa de $65 \%$. Os bancos públicos expandiram o estoque de crédito à indústria, no mesmo período, à taxa de $111 \%$, ao passo que as IFDs-SN o aumentaram em apenas 11\%.

Durante os quatro primeiros anos da série, pode-se considerar que esse desempenho acompanha o comportamento médio das operações de crédito para o setor. De fato, o quadro de estagnação econômica pelo qual passou a economia brasileira nos anos iniciais da década justifica as generalizadas taxas decrescentes registradas nas operaçóes de crédito para a indústria. Entretanto, a partir de 2005, quando finalmente o crédito industrial inicia $o$ 
seu ciclo expansivo, induzido pelos bancos públicos (cuja taxa de crescimento acompanha a média do SFN), as IFDs-SN registram taxa de crescimento bastante modesta quando comparadas à daqueles bancos. O melhor ano para o conjunto das IFDs-SN foi 2009, refletindo a atuaçáo anticíclica implementada pelas IFDs-SN após a eclosão da crise financeira de 2008-2009.

\section{2_Crédito agrícola}

Pelas características inerentes à produção agrícola, sujeita a mudanças climáticas que podem ocasionar quebra de safras - $\mathrm{e}$ a oscilaçóes dos preços, sobretudo quando cotados em mercados internacionais, essa se torna uma atividade inerentemente mais arriscada. Embora tenha sido instituído um dispositivo legal que determina a destinação de $25 \%$ dos recursos oriundos dos depósitos à vista aos empréstimos ao setor rural com o objetivo de fomentar a participaçáo do setor bancário - público e privado -, o setor financeiro público permanece detendo a maior parte do crédito rural no país. $\mathrm{O}$ recente boom nas cotaçóes das commodities (principalmente entre 2003 e meados de 2008) certamente contribuiu para a redução da preferência pela liquidez dos bancos para esse segmento, tendo contribuído para que o crédito rural tenha sido expandido em todos os anos considerados (Tabela 6).
Em decorrência das observações apontadas na seção anterior, isto é, de algumas IFDs-SN registrarem os créditos rurais a pessoas físicas como "pessoas físicas" em vez de "rural", diferentemente da forma como o BCB divulga em suas séries temporais, isso significa que os dados da Tabela 6, a seguir, para as IFDs-SN referem-se apenas ao crédito rural corporativo, ao passo que as colunas referentes ao total do SFN e ao conjunto dos bancos públicos dizem respeito ao crédito rural total. Ainda assim, cabem algumas comparaçóes entre o comportamento do crédito rural via IFDs-SNe o restante do sistema financeiro.

Ao observarmos o comportamento das IFDs-SN em seu conjunto, percebemos que o período de maior expansão de crédito rural se dá na passagem de 2002 para 2003 (37\%). Esse é também o ano em que o conjunto do sistema financeiro nacional mais expande o crédito para o setor rural. O biênio 2003-2004 é o único no qual o crédito rural concedido pelas IFDs-SN segue a tendência do conjunto do SFN; em 2005-2006, o crédito rural via IFDs-SN cresce a uma taxa bastante inferior à do SFN; e em 2007 tal modalidade de crédito encolhe $20 \%$ no caso das IFDs-SN, embora tenha permanecido virtualmente estagnada para a totalidade do SFN e crescido modestamente entre o se- 
Tabela 6_SFN, bancos públicos e IFD-SN -saldo das operações de crédito por setor de atividade

(continua)

\begin{tabular}{|c|c|c|c|c|c|c|c|c|c|c|c|c|}
\hline & $\begin{array}{l}\text { Indústria } \\
\text { SFN } \\
\text { R\$ milhões } \\
\text { de } 2009\end{array}$ & $\begin{array}{l}\text { Taxa de } \\
\text { cresci- } \\
\text { mento } \\
\text { real }(\%)\end{array}$ & $\begin{array}{l}\text { Bancos pú } \\
\text { R\$ milhões } \\
\text { de } 2009\end{array}$ & $\begin{array}{l}\text { Iblicos } \\
\text { Taxa de } \\
\text { cresci- } \\
\text { mento } \\
\text { real (\%) }\end{array}$ & $\begin{array}{l}\text { IFD-SN } \\
\text { RS mi- } \\
\text { lhões de } \\
2009\end{array}$ & $\begin{array}{l}\text { Taxa de } \\
\text { cresci- } \\
\text { mento } \\
\text { real (\%) }\end{array}$ & $\begin{array}{l}\text { Rural } \\
\text { SFN }{ }^{1} \\
\text { R\$ milhões } \\
\text { de } 2009\end{array}$ & $\begin{array}{l}\text { Taxa de } \\
\text { cresci- } \\
\text { mento } \\
\text { real }(\%)\end{array}$ & $\begin{array}{l}\text { Bancos pí } \\
\text { R\$ } \\
\text { milhões } \\
\text { de } 2009\end{array}$ & $\begin{array}{l}\text { úblicos }{ }^{1} \\
\text { Taxa de } \\
\text { cresci- } \\
\text { mento real } \\
(\%)\end{array}$ & $\begin{array}{l}\text { IFD-SN2 } \\
\text { R\$ milhões } \\
\text { de } 2009\end{array}$ & $\begin{array}{l}\text { Taxa de } \\
\text { cresci- } \\
\text { mento real } \\
(\%)\end{array}$ \\
\hline 2001 & 184.877 & - & 67.902 & - & 2.614 & - & 50.818 & - & 29.502 & - & 904 & - \\
\hline 2002 & 173.158 & $-6,34$ & 72.833 & 7,26 & 2.183 & $-16,49$ & 51.862 & 2,05 & 30.563 & 3,6 & 806 & $-10,82$ \\
\hline 2003 & 160.519 & $-7,3$ & 67.923 & $-6,74$ & 2.313 & 5,99 & 64.970 & 25,27 & 39.150 & 28,09 & 1.104 & 36,95 \\
\hline 2004 & 152.495 & -5 & 62.107 & $-8,56$ & 2.012 & $-13,02$ & 71.492 & 10,04 & 41.279 & 5,44 & 1.160 & 5,05 \\
\hline 2005 & 167.770 & 10,02 & 67.921 & 9,36 & 2.072 & 2,99 & 79.637 & 11,4 & 47.299 & 14,58 & 1.240 & 6,95 \\
\hline 2006 & 191.389 & 14,08 & 79.901 & 17,64 & 1.991 & $-3,94$ & 90.334 & 13,43 & 53.107 & 12,28 & 1.269 & 2,32 \\
\hline 2007 & 230.748 & 20,57 & 91.460 & 14,47 & 2.222 & 11,61 & 96.276 & 6,57 & 53.958 & 1,6 & 1.020 & $-19,62$ \\
\hline 2008 & 291.339 & 26,26 & 119.220 & 30,35 & 2.156 & $-2,96$ & 104.536 & 8,58 & 59.603 & 10,46 & 1.162 & 13,94 \\
\hline 2009 & 304.745 & 4,6 & 143.587 & 20,44 & 2.896 & 34,33 & 112.302 & 7,43 & 65.264 & 9,5 & 1.323 & 13,81 \\
\hline 2001-2009 & - & 64,84 & - & 111,46 & - & 10,82 & - & 120,99 & - & 121,22 & - & 46,36 \\
\hline 2001-2004 & - & $-17,52$ & - & $-8,53$ & - & $-23,01$ & - & 40,68 & - & 39,92 & - & 28,31 \\
\hline 2004-2009 & - & 99,84 & - & 131,19 & - & 43,94 & - & 57,08 & - & 58,1 & 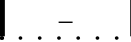 & 14,06 \\
\hline & $\begin{array}{l}\text { Comércio } \\
\text { SFN }\end{array}$ & & Bancos nú & ihlicos & IFD-SN & & $\begin{array}{l}\text { Outros ser } \\
\text { SFN }\end{array}$ & viços & Banco & úblicos & IFD-SN & \\
\hline & $\begin{array}{l}\text { R\$ milhões } \\
\text { de } 2009\end{array}$ & $\begin{array}{l}\text { Taxa de } \\
\text { cresci- } \\
\text { mento } \\
\text { real (\%) }\end{array}$ & $\begin{array}{l}\text { R\$ milhões } \\
\text { de } 2009\end{array}$ & $\begin{array}{l}\text { Taxa de } \\
\text { cresci- } \\
\text { mento } \\
\text { real (\%) }\end{array}$ & $\begin{array}{l}\text { R\$ mi- } \\
\text { lhões de } \\
2009\end{array}$ & $\begin{array}{l}\text { Taxa de } \\
\text { cresci- } \\
\text { mento } \\
\text { real }(\%)\end{array}$ & $\begin{array}{l}\text { R\$ } \\
\text { milhões de } \\
2009\end{array}$ & $\begin{array}{l}\text { Taxa de } \\
\text { cresci- } \\
\text { mento } \\
\text { real (\%) }\end{array}$ & $\begin{array}{l}\text { R\$ } \\
\text { milhões } \\
\text { de } 2009\end{array}$ & $\begin{array}{l}\text { Taxa de } \\
\text { cresci- } \\
\text { mento real } \\
(\%)\end{array}$ & $\begin{array}{l}\text { R\$ mi- } \\
\text { lhõesde } \\
2009\end{array}$ & $\begin{array}{l}\text { Taxa de } \\
\text { cresci- } \\
\text { mento } \\
\text { real (\%) }\end{array}$ \\
\hline 2001 & 68.079 & - & 14.566 & - & 357 & - & 112.074 & - & 30.572 & - & 1.181 & - \\
\hline 2002 & 60.314 & $-11,41$ & 13.090 & $-10,13$ & 416 & 16,57 & 101.383 & $-9,54$ & 30.139 & $-1,42$ & 995 & $-15,73$ \\
\hline 2003 & 59.435 & $-1,46$ & 13.795 & 5,38 & 519 & 24,64 & 98.651 & $-2,69$ & 37.337 & 23,88 & 1.313 & 31,93 \\
\hline 2004 & 66.941 & 12,63 & 15.461 & 12,08 & 524 & 0,96 & 96.810 & $-1,87$ & 40.738 & 9,11 & 1.216 & $-7,39$ \\
\hline 2005 & 77.897 & 16,37 & 17.846 & 15,42 & 560 & 6,88 & 119.760 & 23,71 & 51.014 & 25,22 & 1.219 & 0,28 \\
\hline 2006 & 91.208 & 17,09 & 21.231 & 18,97 & 633 & 12,98 & 141.311 & 17,99 & 62.089 & 21,71 & 1.371 & 12,41 \\
\hline 2007 & 105.381 & 15,54 & 25.254 & 18,95 & 824 & 30,31 & 168.637 & 19,34 & 65.046 & 4,76 & 1.076 & $-21,49$ \\
\hline 2008 & 122.656 & 16,39 & 30.598 & 21,16 & 875 & 6,14 & 215.889 & 28,02 & 88.923 & 36,71 & 1.259 & 16,98 \\
\hline 2009 & 136.306 & 11,13 & 38.274 & 25,09 & 1.356 & 54,96 & 247.687 & 14,73 & 116.847 & 31,4 & 1.459 & 15,91 \\
\hline 2001-2009 & - & 100,22 & - & 162,76 & - & 279,59 & - & 121 & - & 282,21 & - & 23,56 \\
\hline 2001-2004 & - & $-1,67$ & - & 6,15 & - & 46,68 & - & $-13,62$ & - & 33,26 & - & 2,97 \\
\hline 2004-2009 & - & 103,62 & - & 147,55 & - & 158,78 & - & 155,85 & - & 186,82 & - & 19,99 . \\
\hline
\end{tabular}




\begin{tabular}{|c|c|c|c|c|c|c|}
\hline & $\begin{array}{l}\text { Estados e n } \\
\text { SFN } \\
\text { R\$ milhões } \\
\text { de } 2009\end{array}$ & $\begin{array}{l}\text { unicípios } \\
\text { Taxa de } \\
\text { crescimento } \\
\text { real (\%) }\end{array}$ & $\begin{array}{l}\text { Bancos púh } \\
\text { R\$ milhões } \\
\text { de } 2009\end{array}$ & $\begin{array}{l}\text { licos } \\
\text { Taka de } \\
\text { crescimento } \\
\text { real (\%) }\end{array}$ & $\begin{array}{l}\text { IFD-SN } \\
\text { R\$ milhões } \\
\text { de } 2009\end{array}$ & $\begin{array}{l}\text { Taxa de } \\
\text { crescimento } \\
\text { real (\%) }\end{array}$ \\
\hline 2001 & 10.770 & - & 9.539 & - & 165 & - \\
\hline 2002 & 14.200 & 31,86 & 13.004 & 36,32 & 273 & 65,07 \\
\hline 2003 & 14.077 & $-0,87$ & 13.088 & 0,65 & 434 & 59,04 \\
\hline 2004 & 17.304 & 22,92 & 15.262 & 16,61 & 694 & 59,99 \\
\hline 2005 & 19.316 & 11,63 & 15.389 & 0,83 & 763 & 9,91 \\
\hline 2006 & 17.068 & $-11,63$ & 13.367 & $-13,14$ & 775 & 1,55 \\
\hline 2007 & 16.452 & $-3,61$ & 12.771 & $-4,45$ & 974 & 25,65 \\
\hline 2008 & 17.574 & 6,82 & 14.464 & 13,26 & 1.102 & 13,16 \\
\hline 2009 & 26.017 & 48,05 & 23.369 & 61,56 & 1.042 & $-5,43$ \\
\hline 2001-2009 & - & 141,58 & - & 144,98 & - & 530,27 \\
\hline 2001-2004 & - & 60,68 & - & 60 & - & 320 \\
\hline 2004-2009 &.- & 50,35 . & $\therefore$ & $53,12$. & - & 50,06 \\
\hline
\end{tabular}

Fontes: $\mathrm{BCB}$ e informaçōes financeiras trimestrais. Elaboração dos autores.

Notas: 1Inclui pessoas físicas.

${ }^{2}$ Exclui as pessoas físicas - refere-se apenas ao crédito rural corporativo.

tor financeiro público. Em 2008 e 2009, o crédito rural via IFDs-SN volta a expandir-se, em consonância com o conjunto dos bancos públicos. Novamente, os dados evidenciam movimento de expansão das operaçóes das IFDs-SN em 2009, refletindo o papel anticíclico desempenhado por esse conjunto de instituiçóes.

\section{3_Crédito ao comércio}

Segundo Freitas (2009), a melhora do ambiente macroeconômico, em particular a recuperaçáo do emprego e do salário a partir de 2004, refletiu no setor de comércio e de serviços, seja pelas necessidades de ampliaçáo de redes de lojas e postos de venda e armazenagem no primeiro caso, seja na ampliaçáo da frota de veículos pesados, redes de restaurantes, hotéis, etc. Freitas (2009, p. 86) ainda argumenta que o "ciclo do negócio na atividade comercial [é] relativamente mais curto, com rápido giro dos estoques, [sendo] usual nesse setor, sobretudo, no comércio varejista, a ne- 
gociação com os fornecedores de maiores prazos para pagamento", o que reduz a necessidade de financiamento bancário. Isso provavelmente torna menos arriscadas as operaçóes de crédito com esse setor, razão pela qual a destinação de crédito pelas IFDs-SN para o comércio apresenta expressiva expansão durante o período de análise. Além disso, como o setor comércio caracteriza-se por ser trabalho-intensivo, sua necessidade de capital físico é mais reduzida, de modo que suas necessidades de financiamento também o são - e, por isso, a participação do setor comércio no crédito total é inferior à importância do setor em termos econômicos.

Isso posto, a Tabela 6 mostra que os anos de maior crescimento real do crédito ao setor comércio por meio de operações conduzidas pelas IFDs-SN foram 2007 e 2009, nos quais o crédito para esse setor subiu $30 \%$ e $55 \%$, respectivamente. Entre 2001 e 2009, o crescimento, em termos reais, foi de $280 \%$, acima, portanto, da média do SFN (100\%), bem como do conjunto dos bancos públicos (163\%). Entretanto, ao desagregar o período entre antes (2001-2004) e depois (2004-2009) do início do ciclo de crédito, percebe-se uma inflexão nas trajetórias. Entre 2001 e 2004 , houve decréscimo de $2 \%$ do crédito destinado ao comércio pelo SFN. Os bancos públicos, embora não tenham diminuído sua carteira de crédito, registraram taxa de crescimento real modesta, de apenas $6 \%$, ao passo que as IFDs-SN aumentaram em $47 \%$ a destinação de recursos ao comércio, movimento que deve ser explicado à luz das estratégias específicas de algumas instituiçóes, como veremos a seguir. Do mesmo modo, no período 2004-2009, a taxa de crescimento da carteira de crédito comercial das IFDs-SN superou as taxas do SFN e dos bancos públicos. Ou seja, a destinação de créditos para o comércio pelas IFDs-SN, além de acompanhar o ciclo de crédito, ocorre de forma mais intensa.

\section{4_Outros serviços}

Segundo Freitas (2009), o setor de serviços, à semelhança do comercial, caracteriza-se por ser trabalho-intensivo e, portanto, menos dependente do capital físico do que os demais setores, o que tornam reduzidas as suas necessidades de financiamento. Desta forma, sua participação no crédito total também é menos proporcional ao seu peso econômico, alcançando cerca de $30 \%$ em dezembro de 2008 para o conjunto do SFN (Freitas, 2009, p. 13). Para as IFDs-SN, essa relação era bem mais reduzida: $17 \%$.

De acordo com a Tabela 6, a trajetória das operaçóes de crédito a outros ser- 
viços por intermédio das IFDs-SN foi bastante instável, sobretudo se comparada ao SFN. Neste último, as operaçóes de crédito a esse setor iniciam a década registrando taxas de crescimento reais negativas até 2003. A partir do ano seguinte, o crédito a tal modalidade recupera-se, consistindo até mesmo em um dos segmentos indutores do ciclo de crédito recente. Ainda que tenha demorado a reagir ao ciclo de crédito recente, essa modalidade passou a representar parcela crescente das operaçóes de crédito total ao setor corporativo (Freitas, 2009, p. 13). O crédito ao setor serviços pelos bancos públicos começa a recuperar-se já a partir de 2002, diferentemente do que ocorre com as IFDs-SN, que registram também nessa modalidade um comportamento descolado da média do SFN. Por outro lado, por tratar-se de operaçóes cujos prazos são relativamente mais curtos, é razoável supor que as necessidades desse setor tenham sido suficientemente atendidas pela rede de bancos comerciais, o que pode explicar o comportamento descolado por parte das IFDs-SN.

\section{5_Setor público municipal}

As agências de fomento e os bancos de desenvolvimento possuem proibição expressa na Lei de Responsabilidade Fiscal $(L R F)^{19}$ de financiar os respectivos go- vernos estaduais. Por esse motivo, essas operaçōes foram zeradas pelo BRDE em 2007 e pelo BDMG em 2008, já que essas eram as únicas IFDs-SN que financiavam seus governos estaduais na época da criação dessal ei. Atualmente, as IFDs-SN possuem apenas carteira de crédito para o setor público municipal, por meio da qual financiam principalmente o provimento e o reaparelhamento $\mathrm{da}$ infraestrutura. Tal modalidade de empréstimo, no entanto, respondia por apenas $5 \% \mathrm{da}$ carteira de crédito das IFDs-SN em 2008. Apesar da aparente modéstia nos percentuais, o SFN como um todo reservava para os Estados e os municípios apenas 2\% do saldo de suas operações de crédito, e, mesmo entre os bancos públicos, o percentual ainda é baixo: apenas 3\%.

Deste modo, é fácil perceber que, nessa modalidade, as IFDs-SN possuem atuação destacada: de acordo com a Tabela 6 , a taxa de crescimento dos empréstimos das IFDs-SN a Estados e a municípios cresce a uma velocidade bastante superior à do restante do sistema financeiro até 2004, incluindo o conjunto dos bancos públicos. A partir do ano seguinte, os empréstimos nessa modalidade desaceleram para o conjunto do sistema, inclusas as IFDs-SN - contudo, estas últimas desaceleram menos, registrando até surpreendente expansão em 2007.
${ }^{19}$ Art. 36 da Lei

Complementar (LC) no 101, de 4 de maio de 2000. 


\section{7_Prazos das operações de crédito}

De acordo com o Gráfico 5, a seguir, a maior parte da carteira de crédito do conjunto das IFDs é composta de operaçóes cujos prazos variam entre um e cinco anos. Essa categoria oscilou entre $50 \%$ e $55 \%$, durante o período que vai de 2001 a 2009, com tendência de queda até 2005 e ligeira recuperação até 2008. Já a participação dos empréstimos com prazo inferior a um ano tem se reduzido desde 2006: depois de terem oscilado, durante o período considerado, entre $20 \%$ e $25 \%$, tiveram redução substancial entre 2005 e 2006 e estabilizaram-se no patamar de $21 \%$ a

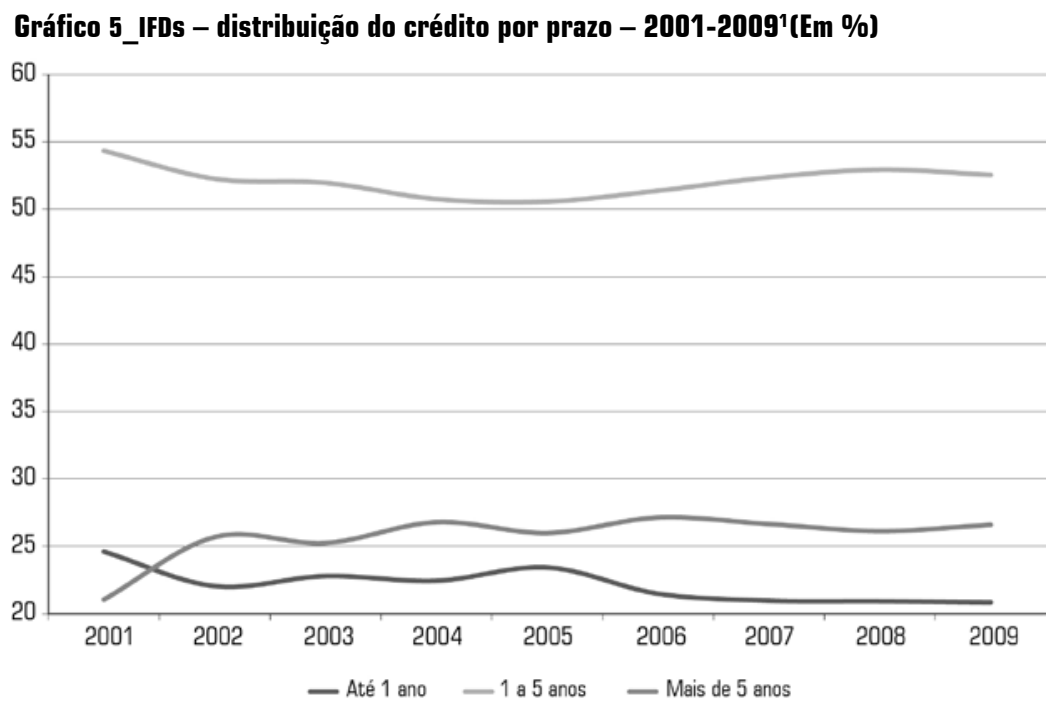

Fontes: $\mathrm{BCB}$ e informações financeiras trimestrais. partir de 2006. Tal redução ocorreu a favor dos empréstimos com prazo superior a 15 anos. Estes, no entanto, ainda representam fatia relativamente pequena quando se considera que o papel primordial de instituiçóes financeiras de desenvolvimento é o financiamento de longo prazo.

A questâo da sustentabilidade financeira também pode ser uma das razóes para justificar que a composição das carteiras de crédito de muitas das IFDs seja pouco favorável às operaçóes de prazo mais longo. Trata-se, tipicamente, de operações mais arriscadas, porque envolvem um horizonte temporal no qual o grau de incerteza é inerentemente mais elevado.

Entretanto, convém que sejam feitas algumas ponderaçōes. A literatura econômica não tem definição exata para financiamento de longo prazo. Esse conceito normalmente está associado a projetos de investimento cujo prazo de maturação é relativamente mais elevado do que em outras modalidades de crédito, como o giro ou o crédito às exportações. Desta forma, é razoável supor que empréstimos com prazos acima de cinco anos correspondam a empréstimos de longo prazo, ao passo queos de prazo inferior a um ano configurem a modalidade de curto prazo.

Já o intervalo que vai de um a cinco anos, tanto pode englobar empréstimos vinculados a investimentos cujo pra- 
zo de maturação esteja no do intervalo, o que é factível, como também pode englobar empréstimos vinculados a outros projetos não considerados investimentos no sentido estrito da formação bruta de capital fixo (FBCF). É o caso, por exemplo, das linhas de crédito destinadas à aquisição de carros para modernização da frota de táxis, disponibilizadas pela Desenbahia, ou então o BDMG Fixo Fácil, que financia, com prazo de até cinco anos, desde a aquisição de veículos para empresas até despesas com licenciamento ambiental e projetos de marketing. Outra explicação está associada ao perfil das IFDs: trata-se de instituiçôes voltadas essencialmente para o financiamento de micros e pequenas empresas, cujas operações são inerentemente mais curtas do que as realizadas por grandes empresas.

De todo modo, o simples fato de a carteira de crédito das IFDs estar concentrada em prazos mais longos é um sinal da funcionalidade desse conjunto de instituições - ainda que fosse desejável que as operaçóes acima de cinco anos fossem preponderantes. Mesmo nos exemplos anteriores de empréstimos voltados para modalidades que, como comentado anteriormente, não configuram investimento propriamente dito, são empréstimos voltados para açóes empreendedoras e que, portanto, são capazes de gerar em- prego e renda, e que provavelmente não seriam atendidas pelo setor privado. Para se ter uma ideia, para os cinco maiores bancos privados que atuam no Brasil, $61 \%$ da carteira de crédito possui prazo inferior a um ano; $34 \%$, entre um e cinco anos; e somente 5\% é superior a cinco anos. BB, CEF, Basa e BNB, bancos que também têm algumas funções específicas de fomento - embora não atuem exclusivamente com esse propósito - também concentram suas operaçóes de crédito nas modalidades mais curtas (Gráfico 6).

Ou seja, é inegável que, quanto aos prazos das operaçóes de crédito, o posicionamento do conjunto das IFDs que compõe o objeto desta pesquisa é mais longo que o dos bancos privados, bem como o do BB, da CEF, do Basa e do BNB. O fato de tratar-se de instituiçóes com perfis distintos, embora óbvio, chama a atenção para a funcionalidade das IFDs em questão: os bancos privados e também os bancos públicos federais aptos a captar depósitos à vista não foram capazes de alongar suficientemente suas carteiras de crédito, fazendo-se necessário o uso de IFDs na típica função que a literatura econômica lhes atribui.

Entretanto, ao compará-las ao próprio BNDES, fica nítida a diferença dos prazos de suas operaçóes de crédito: nesse banco, apenas 3\% de suas operações 
são inferiores a um ano, enquanto $92 \%$ são superiores a cinco anos. Guardadas as evidentes diferenças existentes entre o BNDES e as IFDs que compóem nosso objeto - sejam elas de história, de porte, de fontes estáveis de funding, de público-alvo -, fato é que existe espaço grande para o alongamento dos prazos das carteiras de crédito destas últimas. Os gráficos (Gráfico 6), a seguir, mostram a distribuição do crédito por prazo (2008) dos bancos públicos federais, dos cinco maiores bancos privados e também as IFDs-SN.

Não se pretende propor que a meta das IFDs-SN em questão seja uma carteira de prazo semelhante à do BNDES. Isso porque é possível que, mesmo nas modalidades de curto prazo, as IFDs-SN estejam suprindo crédito não ofertado pela rede privada. Isso pode ser verdadeiro por duas razóes, não necessariamente excludentes. A primeira é a maior competitivida-

\section{Gráfico 6 Bancos públicos federais e cinco maiores bancos privados}

\section{- distribuiçãa do crédito por prazo, 2008 (Em \%)}

5 maiores bancos privados:

composição da carteira de crédito segundo 0 prazo, २००९

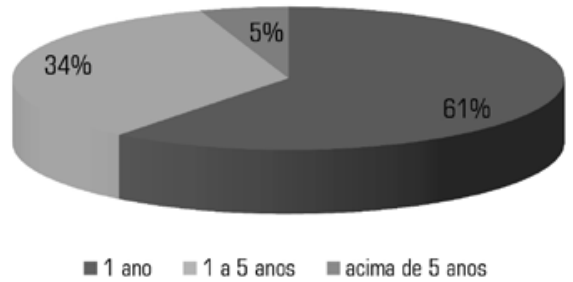

BNDES

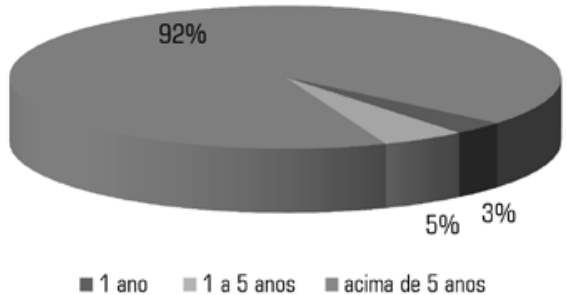

Fonte: Informaçôes financeiras trimestrais/BCB.

Elaboração dos autores.
BB, CEF, BASA e BNB:

composição da carteira de crédito segundo o prazo, २००९

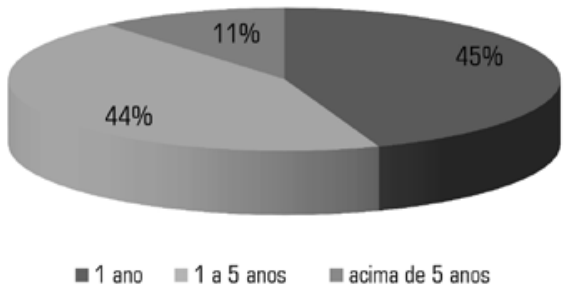

IFDs

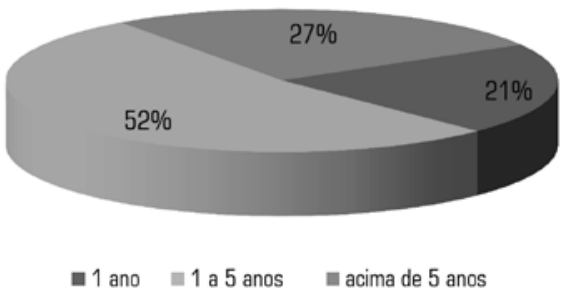


de das taxas nessas operaçóes oferecidas pelas IFDs-SN, sobretudo para micros, pequenas e médias empresas, quando comparadas às dos bancos privados. A segunda é a possibilidade de que, nos Estados da Federação em que o alcance da rede bancária tradicional seja reduzido, as IFDs-SN representam a principal fonte de obtenção de recursos nas modalidades típicas de curto prazo para micros e pequenos empreendedores.

A comprovação de ambas as hipóteses depende de estudos mais aprofundados, o que não é objeto deste trabalho. Quaisquer que sejam as razões (seja pelo perfil das IFDs-SN, mais voltadas para o atendimento às micros e pequenas empresas, seja pelos critérios de rentabilidade, seja ainda pelo suprimento a uma demanda por operaçóes de prazos menores em segmentos não atendidos pela banca privada), é lícito afirmar que existe espaço para que os prazos das operaçóes realizadas pelas IFDs-SN sejam alongados.

\section{8_Considerações finais}

O sistema composto das assim chamadas "instituições financeiras subnacionais" para o desenvolvimento em vigor atualmente no Brasil é bastante heterogêneo, comportando instituiçóes de portes distintos. Em geral, esse sistema possui fontes de funding pouco diversificadas, dependentes de recursos oriundos dos tesouros estaduais e de repasses do BNDES. Assim, as possibilidades de expansão dessas instituiçôes dependem fortemente da dinâmica das respectivas economias estaduais e de sua capacidade arrecadatória; ou de fatores exógenos, tais como o acesso aos recursos do BNDES e dos fundos constitucionais-os quais, por sua vez, dependem da estratégia de atuação do BNDES e dos bancos federais gestores dos fundos constitucionais e dos critérios de escolha dos intermediários financeiros por parte dessas instituições federais.

A análise da carteira de crédito setorial do conjunto de instituiçóes revela que os setores industrial, rural e de pessoas físicas (aqui entendidas como microempreendedores) constituem as maiores prioridades entre as IFDs-SN. Entretanto, os movimentos observados dessas operações indicam também que essas instituições não foram capazes de acompanhar a contento o recente ciclo expansivo de crédito pelo qual passou a economia brasileira desde 2004. De fato, excetuando-se o setor comercial, em todos os demais setores as operações de crédito cresceram a taxas inferiores à média do SFN ou mesmo à dos bancos públicos. $\mathrm{O}$ ano 2009 constitui uma exceção, revelando que as IFDs-SN também contribuíram para a ação 
anticíclica implementada pelos bancos públicos brasileiros por ocasião da crise financeira de 2008-2009.

As dificuldades de expansão da carteira de crédito podem estar relacionadas às limitaçóes das fontes de funding. Maior acesso aos recursos do BNDES e dos fundos constitucionais por parte das IFDs-SN poderá permitir expansão da carteira de crédito dessas instituições. Em princípio, a razão pela qual essa expansão é necessária se apoia no pressuposto teórico segundo o qual instituições financeiras de atuação e sede local tendem a ser mais comprometidas com o desenvolvimento local. A verificação do grau de comprometimento das IFDs-SNcom o desenvolvimento local constitui, assim, importante agenda de pesquisa. 


\section{Referências bibliográficas}

AGHION, B. A. Development banking.Journal of Development Economics, vol. 58 (1999), p. 83100, 1999.

AMADO, A. A questão regional e o sistema financeiro no Brasil: Uma interpretação póskeynesiana. Estudos Econômicos, v. 27, n. 3, p. 417-440, 1997.

AMADO, A. Bancos privados e públicos regionais em uma perspectiva de desenvolvimento regional. In: JAYME JR.,F. G.; CROCCO, M. Banco público e desenvolvimento. Rio de Janeiro: Ipea, 2010.

ARAUjO, V. L. Aplicaçóes dos recursos do FCO ganham mais agilidade.Revista Economia e Desenvolvimento, p. 11-13, 2007. Disponível em:<http://www2. seplan.go.gov.br/seplan/rev/ revista27/cap03.pdf >. Acesso em: 14 jul. 2010.
BANCO NACIONAL DE DESENVOLVIMENTO ECONÔMICO E SOCIAL (BNDES). Critérios para credenciamento, impedimento, suspensão e descredenciamento de agentes financeiros e sociedades de arrendamento mercantil, 2010. Disponível em:<http://www. bndes.gov.br/SiteBNDES/export/ sites/default/bndes_pt/Galerias/ Arquivos/produtos/download/ criterios.pdf $>$.Acesso em: agosto de 2010 .

BOSKEY, S. Problems and practices of development banks. Baltimore: The Johns Hopkins Press, 1959.

BRASIL. Ministério da Integração Nacional. Fundo Constitucional de Financiamento do Nordeste: FNE. 2009a. Relatório de Gestáo, exercício de 2008

BRASIL. Ministério da Integração Nacional. Fundo Constitucional de Financiamento do Norte: FCO, 2009c. Relatório de Gestáo, exercício de 2009

BRASIL. Ministério da Integração Nacional. Fundos Constitucionais de Financiamento: FNO, FNE, FCO. 2009b. Sistema de Informaçóes Gerenciais, Ano XIV, n. 38, exercício de 2008.
CARVALHO, F. C. Sobre a preferência pela liquidez dos bancos. In: PAULA, L. F. \& OREIRO, J. L. Sistema financeiro: Uma análise do setor bancário brasileiro. Rio de Janeiro: Elsevier, 2007.

CAVALCANTE, L. R. Seis personagens à procura de um autor: A inserçấo das agências de fomento e dos bancos estaduais de desenvolvimento no sistema financeiro no Brasil. Revista Desenbahia, Salvador, v. 4, n. 7, p. 7-32, 2007.

\section{CHO, Y. J.; SHENG, A. Risk} management and stable financial. In: CAPRIO, G.; HONOHAN, P.; VITTAS, D. (Ed.). Financial Sector Policy for Developing Countries: Areader. Washington: World Bank, Oxford University Press, 2002.

CINTRA, M. A. M. Crédito público e desenvolvimento econômico: A experiência brasileira.In: FERREIRA, F. M. R.; MEIRELLES, B. B. (Org.). Ensaios sobre economia financeira. Rio de Janeiro: BNDES, 2009. p.57-108.
CROCCO, M.; FIGUEIREDO,

A. T. L. \& SANTOS, F. B.

T. Differentiated banking strategies across the territory: An exploratory analysis. Journal of Post Keynesian Economics, vol. 133, $\mathrm{n}^{\circ} 1,127,2010($ ?).

DIAMOND, W. Development banks. Baltimore, United States: Johns Hopkins University Press, 1957.

DOW, S.C. The regional composition of the money multiplier process Scottish Journal of Political Economy, vol. 19, n. 1, 1982.

\section{FREITAS, C. E. A experiência} brasileira com instituiçōes financeiras de desenvolvimento. Santiago, Chile: Cepal, Unidade de Estudos Especiais, 2005.

FREITAS, M. C. P. Projeto de estudos sobre as perspectivas da indústria financeira brasileira e o papel dos bancos públicos. Campinas: FECAMP, 2009. Subprojeto Mercado de Crédito Bancário. Crédito bancário aos setores de comércio e serviços. Disponível em: <http:// www.iececon.net/arquivos/ Financiamento_Comercio_e Servicos.pdf $>$.Acesso em:?? 
FREITAS, M. C. P.; PRATES, D. M. O mercado de crédito no Brasil: Tendências recentes. In: BIASOTO JR., G.; NOVAIS, L.F.; FREITAS, M. C. P. (Org.). Panorama das economias internacional e brasileira: Dinâmica e impactos da crise global. São Paulo: FUNDAP, Secretaria de Gestão Pública, 2009.

FRY, M. In favourof financial liberalization. The Economic Journal, vol. 107, May 1997.

\section{FUNDO CONSTITUCIONAL DO CENTRO-OESTE}

(FCO). Relatório de atividades desenvolvidas e resultados obtidos do FCO. Exercício de 2009, apud ROSA, C. H. 2010.

\section{FUNDO CONSTITUCIONAL} DO NORTE (FNO). Relatório de atividades desenvolvidas e resultados obtidos do FNO.

Exercício de 2009, apud ROSA, C. H. 2010.

GURLEY, J. G.; SHAW, E. S. Financial aspects of economic development. The American Economic Review, vol. 55, n. 4, 1955.

HERMANN, J. Bancos públicos em sistemas financeiros maduros: Perspectivas teóricas e desafios para os países em desenvolvimento. In: ENCONTRO NACIONAL DA ASSOCIAÇĀO KEYNESIANA BRASILEIRA, 2., 2009, Porto Alegre. Anais... Porto Alegre, 2009.

KEYNES, J. M. Teoria Geral do Emprego, do Juro e da Moeda. Rio de Janeiro: Fundo de Cultura, 1936. Primeira edição de 1964.
KEYNES, J. M. The general theory of employment. The Quaterly Journal of Economics, Cambridge, $M A$, vol. 51, n. 2, p. 209-223, Feb. 1937 [SZMRECSÁNYI, T. (Org.).A teoria geral do emprego. São Paulo: Ática, p. 167-179].

\section{MCKINNON, R. I. Money} ocapital in economic development. Washington, DC.: The Brookings Institution, 1973.

MENEZES, M. et al. Sistema financeiro e desenvolvimento regional: Notas exploratórias. In: PAULA, L. F.; OREIRO, J. L. Sistema financeiro: Umaanálise do setor bancário brasileiro. Rio de Janeiro: Elsevier, 2007.

NOGUEIRA, M.; CROCCO, M.; SANTOS, F. Sistema financeiro e atuação dos bancos públicos no desenvolvimento regional no Brasil.In: JAYME JR., F. G.; CROCCO, M. Banco público e desenvolvimento. Rio de Janeiro: Ipea, 2010.

PINTO, M. A. C.; DE PAULA, P. B.; SALLES, A. B. T. A revitalizaçáo do sistema público de fomento como canal para acesso financeiro por MPMEs. Revista do BNDES, Rio de Janeiro, v. 14, n. 27, p. 141-162, 2007.

SHAW, E. S. Financial deepening in economicdevelopment. New York: Oxford University Press, 1973.

STIGLITZ, J. The role of the State in financial markets. In: ANNUAL BANK CONFERENCE ON DEVELOPMENT ECONOMICS, Washington, DC., The World Bank,1993.
STIGLITZ, J. The efficiency of the financial system and economic development. In: ENCONTRO NACIONAL DE ECONOMIA, 12. dez. 1994, Florianópolis. Anais... Florianópolis, 1994.

STIGLITZ, J. O sistema financeiro e o financiamento do crescimento: Uma alternativa póskeynesiana à visão convencional. In: LIMA, G. T.; SICSÚ, J.; PAULA, L. F. (Org.). Macroeconomia moderna: Keynes e a economia contemporânea. Rio de Janeiro: Campus, 1999.

STUDART, R. The efficiency of the financial system and economic development. In: ENCONTRO NACIONAL DE ECONOMIA, 12., dez. 1994. Florianópolis. Anais... Florianópolis, 1994.

STUDART, R. O sistema financeiro e o financiamento do crescimento: Uma alternativa póskeynesiana à visão convencional. In: LIMA, G. T.; SICSÚ, J.; PAULA, L. F. (Orgs.). Macroeconomia moderna: Keynes e a economia contemporânea. Rio de Janeiro: Campus, 1999.

UNITED NATIONS. Rethinking the Role of National Development Banks. United Nations,

Department of Economic and Social Affairs, 2005.

VITTAS, D.; CHO, Y. J. Credit Policies: Lessons from EastAsia. Washington: The World Bank Policy Research, 1995 (Working Paper, n. 1.458).
YEYATI, E. L.; MICCO, A. \& PANIZZA, U. Should the Government be in the Banking Business? The Role of StateOwned and Development Banks. Inter-American Development Bank, Working Paper 517, 2004.

ZYSMAN, J. Governments, Markets and Growth: financial systems and the politics of industrial change. Londres: Martin Robertson, 1983.

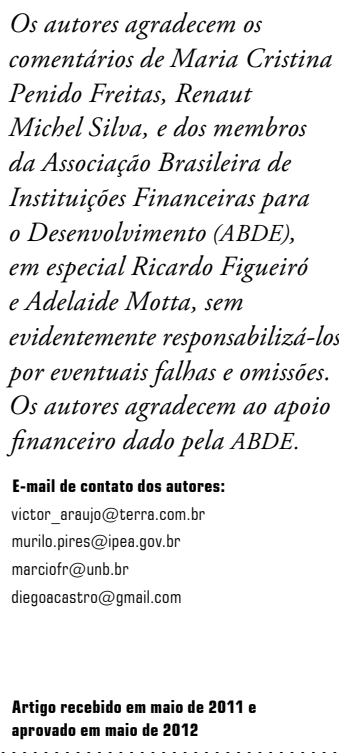


